\title{
Immune memory from SARS-CoV-2 infection in hamsters provides variant-independent protection but still allows virus transmission
}

\author{
Shu Horiuchi ${ }^{*}$, Kohei Oishi ${ }^{*}$, Lucia Carrau' ${ }^{1}$ Justin Frere $^{1}$, Rasmus Møller ${ }^{1}$, Maryline Panis ${ }^{1}$, Benjamin R. \\ tenOever ${ }^{1, \#}$ \\ 1Department of Microbiology, New York University, New York, NY 10016 \\ *Authors contributed equally \\ ${ }^{*}$ Corresponding author. Email: Benjamin.tenOever@NYUlangone.org
}

SARS-CoV-2 has caused significant morbidity and mortality across the globe. As the virus spreads, new variants are arising that show enhanced capacity to bypass pre-existing immunity. To understand the memory response to SARS-CoV-2, here we monitored SARS-CoV-2-specific T and B cells in a longitudinal study of infected and recovered golden hamsters. We demonstrated that engagement of the innate immune system following SARS-CoV-2 infection was delayed but was followed by a pronounced adaptive response. Moreover, T cell adoptive transfer conferred a reduction in virus levels and rapid induction of SARS-CoV-2specific B cells demonstrating both lymphocyte populations contributed to the overall response. Reinfection of recovered animals with a SARS-CoV-2 variant of concern showed that SARS-CoV-2-specific T and $B$ cells could effectively control the infection which associated with the rapid induction of neutralizing antibodies but failed to block transmission to both naïve and seroconverted animals. These data suggest that the adaptive immune response to SARS-CoV-2 is sufficient to provide protection to the host, independent of the emergence of novel variants.

\section{INTRODUCTION}

The host response to virus infection begins at the level of infected cells in mammals $(1,2)$. The cellular intrinsic response to virus is mediated by the production of virus-specific replication intermediates referred to as pathogen-associated molecular patterns (PAMPs) (3, 4). These conserved viral structures are recognized by protein sentinels in the cell which induce the activation of the interferon regulator factor (IRF) and nuclear factor ${ }_{\mathrm{B}} \mathrm{B}(\mathrm{NF}-\mathrm{k} \mathrm{B})$ pathways to coordinate a very sophisticated host immune response $(1,5)$. The host response to virus includes both the induction of type I interferon (IFN-I) to induce the fortification of cellular defenses in nearby cells alongside cytokines which recruit and activate cells of the adaptive immune response (6). The IFN-I response signals to neighboring cells and elicits a second signal transduction event that culminates in the up-regulation of hundreds of interferon stimulated genes (ISGs) which collectively inhibit virus replication (7). Examples of ISGs include the interferon stimulated gene 15 (ISG15) which regulates IFN-I signaling (8) or IRF7, serving to expand the transcriptional footprint of the cell following virus infection (9). Concomitant with the induction of IFN-I biology, infected cells also recruit the adaptive immune response through the induction of chemoattractant cytokines, or chemokines, such as CXCL10 and CCL5 (10-12). Together, these two complementary arms of the defense system limit the immediate spread of virus in vivo while rapidly developing a pathogen-specific immune response that ensures life-long immunity.

Despite the powerful nature of the host antiviral response, virus disease still occurs. Without exception, virus-mediated morbidity and mortality is the product of antagonizing some aspect of the host defense biology. Influenza A virus (IAV) infection results in disease because the virus can successfully mask any aberrant RNA generated during infection through high levels of the non-structural protein 1 (NS1) protein resulting in a minimal transcriptional response in the infected cell (13). In contrast, the transcriptional footprint of severe acute respiratory syndrome coronavirus 2 (SARS-CoV-2) infection also indicates significant interference imposed on host biology as it relates to the response to virus infection. While SARS-CoV-2-infected cells do demonstrate a diminished IFN-I response as a result of a number of virus-specific products reported to antagonize PAMP detection, the infection seemingly demonstrates high levels of NF- $\mathrm{k}$ B activation for reasons that remain unclear $(14,15)$. This process of SARSCoV-2 partially blocking the host innate response results in a lack of local replication control alongside high level of proinflammatory cytokines and chemokines which may constitute the molecular basis of coronavirus disease-2019- ultimately 
resulting in COVID-19. These data have also been corroborated using both clinical data and the golden hamster model (16-18).

The development of immune memory is initiated by antigen presenting cells which present peptide fragments of the virus to induce activation and differentiation of $\mathrm{CD} 4+$ and CD8 + $\mathrm{T}$ cells that express a $\mathrm{T}$ cell receptor (TCR) capable of engaging the material presented. Effector CD4+ T cells further induce virus-specific $\mathrm{B}$ cell receptor (BCR) expressing $\mathrm{B}$ cells which contribute to antibody production. Effector CD8+ $\mathrm{T}$ cells function as cytotoxic T cells (CTL) and play a key role in virus clearance. After virus clearance, a small subset of virus-specific $\mathrm{T}$ and $\mathrm{B}$ cells survive indefinitely as memory cells. These memory $\mathrm{T}$ and $\mathrm{B}$ cells have the ability to respond rapidly after re-infection to clear the virus efficiently (19-22). Here we focus on how SARS-CoV-2 modulation of host antiviral biology contributes to the immune memory response.

Vaccination against SARS-CoV-2 Spike protein (here noted as $\mathrm{S}$ ) is a highly effective means of preventing the development of COVID-19 (23). For SARS-CoV-2 infection, virus-specific $\mathrm{T}$ and $\mathrm{B}$ cells are detectable in the blood for up to 8 months after vaccination in humans, suggesting the presence of memory cells generated by the vaccine (24). However, the effectiveness of this memory response in blocking transmission or re-infection from SARS-CoV-2, or one of the variants that have arisen as a result of positive selection, remains unknown as immunological data concerning COVID-19 has relied heavily on clinical data which lacks the specific controls and experimental designs one can achieve with a small animal model (25-27).

As the golden hamster model has proven to largely phenocopy COVID-19 biology, here we aimed to determine the memory response to SARS-CoV-2 $(18,28-31)$. To this end, we developed the necessary tools to analyze the adaptive immune response in the golden hamster. We found that SARSCoV-2 infection induced a strong adaptive immune response compared to IAV, and generated virus-specific $\mathrm{T}$ and $\mathrm{B}$ cells that were preserved as memory cells after viral clearance. Moreover, establishment of the memory response also protected animals from re-challenge, with the SARS-CoV-2 beta variant infection showing a significant decrease in viral titer and a corresponding increase in cross reactive antibody production as compared to the control cohort. These data could be further resolved through the use of adoptive transfers of memory $\mathrm{T}$ cells which we found conferred reduction in virus levels following the rapid induction of SARS-CoV-2 specific B cells, although transmission potential remained unchanged. These results shed light on the importance of memory $\mathrm{T}$ and B cells for protection against re-infection with SARS-CoV-2 and its emerged variants.

\section{RESULTS}

Innate immune engagement correlates with the

\section{timing of viral clearance.}

In an effort to better understand the immune response to SARS-CoV-2, we compared this infection to challenge with an unrelated RNA respiratory virus responsible for a past pandemic (Influenza A/California/04/2009) $(18,32)$. The idea to compare these two viral platforms was to provide a benchmark for hamster immunity by including a virus model that has been extensively studied to better understand how the response to SARS-CoV-2 may differ. In this regard, intranasal inoculation of influenza A virus (IAV) resulted in robust replication in the respiratory tract showing peak titers of $\sim 10^{8}$ plaque forming units (pfu) at 3 days post-infection (dpi). Despite the high viral load, IAV was rapidly cleared from the lungs showing no infectious particles by $7 \mathrm{dpi}$ (Fig. 1A). This replication trajectory was similar when comparing the titers of SARS-CoV-2 Washington strain (SARS-CoV-2WA), with the highest virus levels being achieved at 3dpi with virus levels reaching $\sim 10^{8}$ pfu (Fig. 1B). In contrast, while IAV clearance was already evident starting at 5dpi, SARS-CoV-2WA dynamics showed continual virus production with little change in titers until 7dpi (Fig. 1A and 1B). The inability to control SARS-CoV-2WA also correlated with body weight as infected animals showed delayed growth as compared to both mock and IAV-infected animals (Fig. S1A).

To assess the innate immune responses in these model systems, we performed mRNA-seq at 3 and 5 dpi lungs to determine differential gene expression (DEG) in the respiratory tract. Reflecting viral titers, IAV-infected hamsters showed a transcriptional footprint indicative of NF- $\mathrm{B}$ activation including high levels of chemokines at 3dpi (Fig. 1C and 1D). In contrast, at $5 \mathrm{dpi}$, these signatures largely returned to baseline correlating with the decrease in IAV titers (Fig. 1A and $1 \mathrm{C}$ and 1D). These results suggest a diminished IFN-I response that enabled IAV titers to reach $\sim 10^{8}$ pfu but a subsequent strong induction of an NF- $\mathrm{kB}$-mediated response which successfully cleared the infection. In contrast to IAV, SARS-CoV-2WAinfected hamsters showed a delayed induction of NF- $\mathrm{kB}-$ related genes, requiring two additional days to generate a comparable response to that observed for IAV despite similar viral loads (Fig. 1A and 1C and 1D). Together these data demonstrated a delayed induction of innate immune response upon SARS-CoV-2WA infection (Fig. 1E). The delay in the host antiviral response following SARS-CoV-2WA infection as compared to IAV was further corroborated by qRTPCR for key genes involved in the IFN-I system (Isg15 and Irf7) and chemokines (Cxcl10 and Ccl5) (Fig. 1F). These results reflect the interactions between host and virus, suggesting that SARS-CoV-2 can antagonize aspects of the host response in the hamster model more potently than IAV.

\section{Adaptive immunity to SARS-CoV-2 infection exceeds the response to $\mathrm{LAV}$}

To compare the adaptive immune response to SARS-CoV- 
2 versus IAV, we analyzed T and B cell frequency in the lung after viral clearance by developing an assay to characterize immune cells by Fluorescence-activated cell sorting (FACS). Given the limitations of available reagents for the golden hamster, we first tested antibodies that cross-reacted with divergent species and therefore were likely to recognize the ortholog in hamsters (33-35). In addition to reported crossreactive antibodies, we also combined commercialized antigolden hamster antibodies and adjusted the titration to create the greatest disparity between different cellular populations to aid in our immune cell profiling (Fig. S2A-C). Based on these markers (MCHII, CD3, CD4, Bcl6, FoxP3, CXCR3, CXCR5, IgG2, and IgG), we profiled total lymphocytes, T cells, and $\mathrm{B}$ cells in the lungs which conformed to the general frequency observed in other model vertebrates (36). After gating total lymphoid populations and screening out dead cells, total T cells were defined as CD3+MHCll- whereas B cells were denoted as CD3-MHCll+. Subset of T cells could be further delineated as $\mathrm{CD} 4+\mathrm{T}$ cells by gating on $\mathrm{CD} 3+\mathrm{CD} 4+$ whereas $\mathrm{CD} 8+\mathrm{T}$ cells were defined by CD3+CD4-. CD4+ T cell subsets were further separated by the expression of CXCR5, CXCR3, FoxP3, and Bcl6. CXCR3+FoxP3- as Th1, CXCR3-FoxP3+ as Treg, and CXCR5+Bcl6+ as Tfh cells. CD8+ T cells were subdivided as CXCR3+ vs CXCR3- CD8+ T cells. Lastly, B cell isotypes were identified as either IgG2+ or IgG2-IgG+ to denote class switch in addition to being Bcl6+ versus Bcl6- indicating germinal vs. non-germinal B cells, respectively (Fig. S2A).

To profile the host adaptive immune response to SARSCoV-2 and IAV, hamsters were infected intranasally or treated with PBS as a non-infected control (Fig. 2A). T and B cell populations in the lungs at 7 and 14dpi were analyzed by FACS using the gating strategies outlined above (Fig. S2A). The ficol separated cell number after ficol separation was significantly elevated in response to SARS-CoV-2WA at 7 dpi suggesting increased lymphoid cell migration in agreement with the enhanced chemokine expression profile observed (Fig. 1C and 2B). Profiling total T cells (CD3+) demonstrated a significant increase in frequency following SARS-CoV-2WA infection as compared to IAV at $7 \mathrm{dpi}$ which returned to baseline in all cohorts by 14dpi (Fig. 2C). To further delineate the nature of this increased frequency, we again profiled total $\mathrm{T}$ cells for CD4 expression to reveal that SARS-CoV-2WA induced a dramatic increase specific to CD8+ cells (CD4-CD3+) (Fig. 2D).

Next, determined the frequency of Th1 and FoxP3+ Treg cells as these have been implicated in the respiratory response to virus infection $(22,37,38)$. In agreement with published studies, both IAV and SARS-CoV-2WA infection induced CXCR3+ Th1 cells (Fig. 2E). In contrast, we observed differences in CXCR3-/FoxP3+ Treg cells in response to SARS-CoV-2WA which were significantly lower when compared to IAV which had a corresponding increase in
CXCR3+/FoxP3+ cells (39) (Fig. 2E and S2C). Profiling the frequency of CXCR5+Bcl6+ Tfh cells showed a significantly more robust response to SARS-CoV-2WA as compared to IAV which was sustained for the duration of the experiment (Fig. $2 \mathrm{~F})$. Given recent evidence for the role of CD8+ cells in combating a respiratory viral infection (40), we measured CD3+/CXCR3+CD4- populations and found SARS-CoV-2WA infection induced stronger CD8+ T cells in the lung (Fig. 2E), as compared to IAV, suggesting robust infiltration consistent with COVID-19. Taken together, these data demonstrate a dramatic change in CD4+ T cell subsets in response to SARSCoV-2WA. Despite showing no increase in total cell number over mock or IAV-infected animals, SARS-CoV-2WA infection induced a dramatic loss of Tregs with a contrasting increase in Tfh and CD8+ T cells (Fig. 2F and 2G). Lastly, we profiled $\mathrm{B}$ cells in these model systems but found no significant difference between the response to SARS-CoV-2WA and IAV (Fig. S2D and S2E). Collectively, we concluded that SARS$\mathrm{CoV}-2$ infection induces a stronger effector $\mathrm{T}$ cell response in the lung compared to IAV infection.

\section{Antigen-specific $T$ and $B$ cells generated after SARS- CoV-2 infection are maintained as memory cells}

Given the unique adaptive immune response to SARSCoV-2 in the initial phase on of infection, we next chose to evaluate the generation of memory $\mathrm{B}$ and $\mathrm{T}$ cells. To assess the memory response, it is imperative to perform longitudinal studies to identify times of peak infiltration followed by a return to baseline. To this end, we infected golden hamsters with SARS-CoV-2WA and obtained lung, lung draining mediastinal lymph node (mLN), blood and/or spleen at day 7, 14, and 42dpi (Fig. 3A). Based on cell frequency, we defined the acute phase of the immune response to SARS-CoV-2WA to encompass the first 14dpi (Fig. S3A and S3B). In contrast, at 42dpi, we observed the memory phase as defined by a contraction of the frequency of immune cell population (Fig. S3A and S3B).

To identify antigen-specific $\mathrm{T}$ and $\mathrm{B}$ cells in golden hamsters, we combined several methods widely used in human studies (41-44). For SARS-CoV-2-specific CD4+ T cells, ficol separated cells collected from either lungs, peripheral blood mononuclear cells (PBMCs), mLNs, or spleens were cultured for 24 hours in the presence of a titrated SARS-CoV-2 Spike $(\mathrm{S})$, nucleocapsid $(\mathrm{N})$ and matrix $(\mathrm{M})$ peptide mix after overnight resting. These data identified a CD4+ T cell population with high levels of Ki67 and IRF4 indicating specific recognition of the aforementioned peptides and a productive adaptive response $(41,43)$ (Fig. S3C and S3E).

In an effort to evaluate the B cell response to infection, biotin-labeled SARS-CoV-2 S protein was added to individual immune cells from either lungs, PBMCs, mLNs, or spleens in the presence of two fluorescently labeled streptavidins (BV786 and BV650). In this assay, B cells capable of 
recognizing antigens of $\mathrm{S}$ will bind the biotin-labeled substrate which then further associates with both streptavidin fluorophores. To ensure specificity, we performed this assay using solenocytes from either SARS-CoV-2WA- or IAVinfected hamsters prior to the experiment (Fig. S3D).

Upon establishing a methodology for antigen-specific B and $\mathrm{T}$ cells in the hamster model, we next applied it to our acute and memory phase following SARS-CoV-2WA infection. SARS-CoV-2-specific CD4+ T cells and S-specific B cells were detected at 7- and 14-dpi (Fig. 3B and C). The frequencies of antigen-specific cells were variable depending on both time post infection and cell population tested. These data demonstrated a robust antigen-specific CD4+ $\mathrm{T}$ cell response in the lung as early as $7 \mathrm{dpi}$ that diminished thereafter but was still present at 14dpi (Fig. 3B). In PBMCs, SARS-CoV-2-specific $\mathrm{CD} 4+\mathrm{T}$ cells were undetectable at 7dpi but significantly increased in frequency thereafter (Fig. 3B). Similar trends for SARS-CoV-2-specific B cells could be observed in the lung and PBMCs as compared to CD4+ T cells; with the lung showing a high frequency of antigen-specific cells at 7dpi which decreased over time in contrast to blood where this pattern was inversed (Fig. 3C). For B cells, we also examined the mLN and found SARS-CoV-2-specific cells showing the same trend in frequency as PBMCs (Fig. 3C).

After acute infection, a subset of the antigen-specific cells are preserved for a long time in the body as memory cells (45). In clinical samples of SARS-CoV-2, memory T and B cells were detected in peripheral blood for up to 8 months (24). To determine if SARS-CoV-2 infection in golden hamsters could induce memory $\mathrm{T}$ and $\mathrm{B}$ cells, we next examined the immune cell population beyond 40dpi (Fig. 3D and 3E). Interestingly, we found SARS-CoV-2-specific CD4+ T cells in the lungs of hamsters five weeks post viral clearance (Fig. 1A and 3D). SARS-CoV-2-specific-CD4+ T cells could also be observed in the spleen beyond 40dpi but were below the level of detection in PBMCs (Fig. 3D). Parallel trends observed between T and $B$ cells during the acute phase of infection were also mirrored beyond 40dpi with SARS-CoV-2-specific B cells displaying high frequencies in the lung, spleen, and PBMCs (Fig. 3E). As expected, antibodies recognizing the receptor binding domain (RBD) of $\mathrm{S}$ as well as general neutralization antibody titers peaked within two weeks and decreased thereafter, plateauing at levels that maintained significance over mock (Fig. 3F and 3G). Together, these data suggest that SARS-CoV2 infection in hamsters induces antigen-specific $\mathrm{T}$ and $\mathrm{B}$ cells that are preserved as memory cells.

\section{Adaptive immunity protects the host but does not prevent transmission after secondary exposure to SARS-COV-2}

Clinical studies from recovered SARS-CoV-2 infected individuals have demonstrated a decrease in antibody titer and antigen-specific $\mathrm{T}$ and $\mathrm{B}$ cells $(46,47)$. Despite being a relatively normal immune phenomenon, these findings gave way to concerns about the possibility of re-infection. Given that these trends were also observed in our golden hamster model, we next subjected a cohort of SARS-CoV-2WArecovered hamsters ( 4 months post primary infection) to rechallenge (Fig. 4A). Re-challenged animals were monitored for infectious virus from both nasal washes and lung tissue, demonstrating near-complete protection amongst sero-converted animals (Fig. 4B). These data suggest that hamsters who have recovered from SARS-CoV-2 infection are protected from re-infection for at least four months post clearance.

To determine if this level of individual protection also prevented the ability of seroconverted animals to transmit virus, we next co-housed re-challenged animals at 1dpi (and four months prior to primary infection) with naïve animals (Fig. 4A). To mitigate the possibility of direct viral carryover from the re-challenged animals, we waited 1 day post virus administration and moved both the re-challenged and naïve animals to a new cage. These data found that despite our inability to detect a single infectious particle from nasal washes, transmission was observed in all eight transmission experiments where virus levels were robust in both the nasal washes and lungs of the naïve exposed animals (Fig. 4C). Examining the re-challenged animals demonstrated that despite the detection of SARS-CoV-2-specific B cells, the amount of antibody was similar to that detected at 72 dpi (Fig. 3F, Fig. S4A-B). The frequency of SARS-CoV-2-Spike specific B cells and anti-RBD specific antibody titers did not correlate after SARS-CoV-2WA re-infection (Fig. S4C). These results suggest that the antibody titer and the presence of SARS-CoV-2-Spike specific B cells are not the result of an memory response. Hence, protection of these animals after second infection may have been the result of residual antibodies from the primary infection (Fig. S4A-S4D). Taken together, these data suggest that recovered individuals are protected from re-infection of the same SARS-CoV-2-specific strain but maintain the capacity to transmit virus.

\section{SARS-CoV-2-specific memory $T$ cells contribute to vi- ral clearance}

To assess the specific contribution of the memory $\mathrm{T}$ cell response we first needed to control for any interference from residual antibodies derived from the primary infection (Fig. S4A-S4C). To this end, we established an adoptive transfer system for the golden hamster as previous studies have determined that these animals are sufficiently inbred to prevent graft vs. host disease (48). We isolated and treated total lymphoid cells with the cell trace violet (CTV) reagent prior to transferring them to naïve animals. We confirmed that lymphoid cells collected from the lungs and spleens of naïve donors remained in the recipient hamsters in all organs tested for up to four days post intravenous administration by the presence of CTV (Fig. S5A and S5B). Having demonstrated 
the feasibility of this technique, we next collected lymphoid cells from lungs, PBMCs and spleens from SARS-CoV-2WA recovered animals (40dpi) and transferred them to naïve recipients (Fig. S5C). One day post adoptive transfer, treated animals were infected with SARS-CoV-2WA and blood was collected at 3 and 8dpi. At 3dpi, we observed a significant boost in anti-RBD antibodies as compared to animals transfused with control cells and challenged (Fig. S5D). These data indicate that our transferred B cells produced functional antibodies in the recipient animals. At 8dpi, we observed that the primary response to virus outcompetes any boost provided by the adoptive transfer (Fig. S5D).

To parse out the contribution of $\mathrm{T}$ vs $\mathrm{B}$ cells in this memory response, we next repeated the adoptive transfer following B cell depletion by using anti-MHCll, anti-IgG, and anti-IgM with the combination of magnetic beads from immune cells derived from lungs, PBMCs, and spleens (Fig. S5E and S5F). Adoptive transfer of these individual enriched $\mathrm{T}$ cell populations was administered to hamsters one day prior to SARS-CoV-2WA infection (Fig. 5A). Virus titers from treated animals were determined from nasal wash at 1,3 , and 5dpi (Fig. 5B). These data demonstrated that memory T cells from recovered hamsters contribute to early virus clearance in the upper respiratory tract as titers from SARS-CoV-2WA recovered animals all demonstrated significantly lower viral loads (Fig. 5B). Of note, we observed some baseline differences in viral load between different cohorts suggesting that the administration of different cell lineages may result in distinct host responses that might influence virus replication. As the results derived from this data only compared within treatment cohorts, we are still able to conclude that lung cells, PBMCs, and splenic cells from previously infected animals all provide a level of protection. The observed decrease in viral titers from SARS-CoV-2WA recovered T-cell donor recipients were also reflected in total lung where virus levels trended downwards from all $\mathrm{T}$ cell populations tested (Fig. 5C). Lastly, as CD4+ T cells contribute to antibody production during virus infection in the lung (36), we analyzed the frequency of S-specific B cells from SARS-CoV-2WA recovered CD3+ T cell transferred donor hamster organs after infection. $\mathrm{S}$-specific B cells were readily detectable in all donors who received $\mathrm{T}$ cells from recovered recipients (Fig. 5D). These data suggest the presence of SARS-CoV-2-specific memory $\mathrm{CD} 3+\mathrm{T}$ cells contribute to early induction of virus-specific antibodies without the presence of memory B cells

Memory $B$ and T cells generated after SARS-CoV-2 infection contribute to $S A R S-C o V$ - 2 variant clearance

The recent emergence of multiple variants displaying different $\mathrm{S}$ mutations have caused significant concern worldwide as their potential to evade pre-existing immunity could result in a second pandemic (49-53). This concern has been partially justified as variants such as the B.1.351 beta variant
(SARS-CoV-2 $\beta$ ) demonstrate some level of antibody evasion when tested in vitro (49-54).To evaluate the possibility of variants evading pre-existing immunity in the context of a physiological model, we next challenged hamsters that had recovered from the SARS-CoV-2WA with the same variant (SARS-CoV-2 $\beta$ ) in vivo.

As previously reported, we could confirm using our hamster model that the antibodies elicited by challenge with SARS-CoV-2WA were less neutralizing for SARS-CoV-2 $\beta$ when tested in vitro (Fig. 6A). However, as the host response to virus infection requires both $\mathrm{B}$ and $\mathrm{T}$ cells, we next evaluated this same dynamic in vivo (Fig. 6B). Nasal washes from either naïve or previously exposed animals re-challenged with the SARS-CoV-2 $\beta$ variant showed comparable titers in the upper respiratory tract at 1 and 2dpi (Fig. 6C). However, at 4dpi, animals that had been previously exposed to the SARS-CoV-2WA showed complete clearance in contrast to the control group where infectious material could be detected until 5dpi (Fig. 6C). These results were further corroborated in lung titers (Fig. 6C). To ascertain how the memory response may contribute to these findings, anti-SARS-CoV-2 Sspecific B cells and SARS-CoV-2 RBD antibody titers were analyzed (Fig. $6 \mathrm{D}$ and $6 \mathrm{E}$ ). These analyses demonstrated that SARS-CoV-2 S-specific B cells and RBD-specific antibodies were robustly induced (Fig. 6D and 6E). Correlations between RBD antibody titer and WA S-specific B cell frequencies in these animals suggest the successful establishment of an immune memory response (Fig. 6F, Fig. S6). Additionally, SARSCoV-2 $\beta$ re-infected hamsters showed strong increase in neutralization titer against both SARS-CoV-2WA and SARS-CoV$2 \beta$ (Fig. 6G). Moreover, these results suggest that SARS-CoV$2 \mathrm{~S}$-specific memory B cells reactivate in the lungs and/or spleens of recovered individuals and may induce cross-reactive antibodies to both SARS-CoV-2WA and the SARS-CoV-2 $\beta$ variant. In all, these data demonstrate that $\mathrm{B}$ and $\mathrm{T}$ cell memory generated after SARS-CoV-2 infection can re-adjust and contribute to the clearance of related variants.

\section{DISCUSSION}

Viruses are not inherent drivers of morbidity and mortality. Despite the global burden imposed by viruses, these represent only a small fraction of the vertebrate virome (55). The vast majority of viruses do not cause disease and can be readily controlled by our immune system. What makes pathogens noteworthy is their capacity to antagonize our antiviral biology. Characterization of IAV and SARS-CoV-2 infections has demonstrated that both viruses dampen production of IFN-I, albeit with different kinetics and potency. We found that the innate host response to SARS-CoV-2 was delayed when compared to IAV, a dynamic that provides an explanation for how COVID-19 develops. However, this virus-host interaction is only a partial contributor to the biology of SARS-CoV-2. Here we further focused on the development of the memory 
response to SARS-CoV-2. Recent studies have suggested the possibility of memory $\mathrm{T}$ cells participating in the protection against SARS-CoV-2 and variant of concerns in humans (24, 56). However, there are very few studies that demonstrate $\mathrm{T}$ cell protection after secondary infection $(28,57,58)$. Because the golden hamster model has proven to largely phenocopy COVID-19 biology, we aimed to determine the functionality of the memory response to SARS-CoV-2.

To define the breadth of immune memory to SARS-CoV2 , we first needed to identify reagents that could monitor key immune cells in a model system with little to no commercial reagents available. To analyze hamster markers by FACS, we introduced cross-reactive antibodies commercialized for human and murine targets. While some of the antibodies utilized for this assay were previously reported (33-35), this was the first study demonstrating the use of cross-reactive antibodies, CXCR3, CXCR5, and Bcl6 for hamster research. Of note, the cellular expression patterns from these antibodies are consistent with our present understanding of the frequency of different immune cell populations. Upon developing the methodology to monitor the adaptive immune response to SARS-CoV-2 in the hamster, we focused on the behavior of $\mathrm{T}$ and $\mathrm{B}$ cells in various immune compartments. These data revealed an expansion of immune cells in response to SARS-CoV-2 including the establishment of a memory response. Interestingly, SARS-CoV-2 included a significant population of resident memory $\mathrm{T}$ cells in the lung which may serve to protect virus infection in the airway, similar to what has been described for $\operatorname{IAV}(59,60)$.

To better define the individual contributions of $\mathrm{T}$ and $\mathrm{B}$ cells, we next performed an adoptive transfer of only $\mathrm{T}$ cells from previously infected animals. These data demonstrated that virus titers could be lowered, even in the near absence of B cell support, suggesting that T cells can directly contribute to the inhibition of virus and illustrating the formation of immune memory to SARS-CoV-2. Given these results, we next focused our model on addressing two important and unanswered questions as it pertains to memory. First, we sought to determine if transmission was interrupted following the establishment of memory. Second, we chose to examine whether memory to the founder strain of SARS-CoV-2 was sufficient to protect the host from the emerging variants. Based on previous studies we know vaccination reduces the risk of transmission but does not prevent it outright, a result that is compatible in the golden hamster model $(61,62)$.

Here we demonstrated that despite the delay in the initial cellular response to infection, SARS-CoV-2 induced a canonical adaptive host response that culminates in the establishment of immune memory. However, despite this, we found that generation of SARS-CoV-2-specific $\mathrm{B}$ and $\mathrm{T}$ cells failed to block transmission despite showing detectable infectious particles in those animals that had seroconverted. In the case of the hamster model, very low amounts of infectious particles are still sufficient to be transmitted $(18,28)$. We believe that the amount of virus necessary for transmission was below our level of detection and thus allows for the transmission events observed. These data have very significant implications for this pandemic as it would suggest that individuals that are vaccine hesitant will remain at risk indefinitely as SARS-CoV-2 may continue to circulate globally for years to come without the knowledge of those who have recovered from or been vaccinated for the virus.

As the golden hamster is not a commonly utilized small animal model, these studies required some level of unconventional methods to monitor host immunology in the absence of certain commercial reagents. For example, identification of $\mathrm{T}$ and $\mathrm{B}$ cell populations were only possible with limited number of commercialized anti-hamster antibodies and cross-reactive antibodies which were performed using flow cytometry. For this reason, we were also not able to identify $\mathrm{B}$ cell-specific or CD8+ T cell populations. Moreover, as CD3 staining was only possible after fixation, we were not able to sort live cells for this population. Lastly, because the lymphocyte culture condition was not adjusted to hamsters and also, the antibodies we use are detecting the target by cross reactivity, chemokine markers were not detectable after stimulation and culture. Also, because we were not able to stain CD8+ T cells by anti-CD8 antibodies, the background of Ki67 and IRF4 were too high to identify the stimulation specific increase of the population. Therefore, we were not able to provide high resolution of antigen-specific CD8+ $\mathrm{T}$ cells or subsets of CD4+ T cells in this assay.

Lastly, we addressed the growing concern that the emergence of the SARS-CoV-2 variants may to lead to another pandemic wave even amongst vaccinated and/or recovered induvial. This concern is mainly based on the position of many of the mutations that have emerged in the $S$ open reading frame located near a site commonly recognized following seroconversion. Antibodies generated to the parental strain have been found to be neutralizing to many of the widely circulating variants (25-27). However, as the virus neutralization assay was performed by incubating serum and virus in vitro (63), it does not account for the contribution of $\mathrm{T}$ cells and other aspects of the immune response that can only be achieved under physiological conditions. The SARS-CoV-2 rechallenge study has been conducted in other reports $(63,64)$. To this end, we challenged animals that had previously recovered to the parental strain of SARS-CoV-2 and compared these animals with an established memory response to a de novo challenge experiment with the beta variant of SARS$\mathrm{CoV}-2$. The results of this re-challenge experiment showed no initial difference in the host response confirming an absence of residual antibodies or inflammation. However, despite the common trajectory of virus replication prior to day four, at 
this time point the cohort phenotype bifurcated dramatically with pre-exposed animals showing a complete loss of infectious virus. These data demonstrate that memory response to even the founder strain of SARS-CoV-2 was sufficient to neutralize infection of a variant that deviates from the founder $\mathrm{S}$ attachment protein. Taken together, this work demonstrates that although the establishment of immune memory does not prevent SARS-CoV-2 transmission, it is sufficient at protecting us against both the founder and the variant of concern suggesting that with aggressive vaccination campaigns, this pandemic can be resolved.

\section{MATERIAL AND METHODS \\ Study design}

This study characterizes the innate and adaptive immune response in golden hamsters following SARS-CoV-2 infection. Golden hamsters were intranasally challenged by SARS-CoV$2\left(10^{3} \mathrm{pfu}, 100 \mu \mathrm{l}\right)$ or IAV $\left(10^{5} \mathrm{pfu}, 100 \mu \mathrm{l}\right)$ to analyze the host response. At indicated time points, lung were collected and used to define virus titer, assess gene expression changes and monitor immune cell profiles by flow cytometry. To this end, we established a flow cytometry-based assay to identify both total and SARS-CoV-2-specific T and B cell populations. All animals were purchased from Charles River Laboratories and the studies were conducted in accordance with animal welfare and IACUC guidelines. All experiments involving virus infections were carried out in a CDC/ USDA-approved high containment biosafety level three facility.

\section{Viruses}

SARS-related coronavirus 2 (SARS-CoV-2) isolate USAWA1/2020 (NR-52281) and B.1.351 beta variant was deposited by the Center for Disease Control and Prevention (Atlanta, GA, USA) and obtained through BEI Resources, NIAID, NIH (Bethesda, MD, USA). Each SARS-CoV-2 strain was initially plaque purified, propagated in Vero-E6 cells with DMEM supplemented with $5 \% \mathrm{FBS}$, and subsequently genotype verified by RNA-Sequencing, Influenza A virus (A/California/04/2009) was propagated in MDCK cells with EMEM containing $3 \%$ BSA and $1 \mu \mathrm{g} / \mathrm{ml}$ TPCK-trypsin.

\section{In vivo infections and harvest}

Before intranasal infection, hamsters were anesthetized by intraperitoneal injection with 200 ul of a ketamine/xylazine solution (3:1), [100 mg/kg]. $10^{3}$ pfu of SARSCoV-2 or $10^{5}$ pfu of IAV stock was resuspended in $100 \mathrm{ul}$ of PBS. 100 ul of PBS or each virus was administered intranasally for each animal. Hamsters were euthanized by intraperitoneal injection of Pentobarbital. Blood was collected from the aorta during necropsy at the end of each indicated time point.

\section{Plaque assay}

Virus titers of IAV and each SARS-CoV-2 strain were determined by means of plaque assay in MDCK cells or Vero-E6 cells, respectively. At $48 \mathrm{~h}$ post-infection, plaques were fixed in $5 \%$ formaldehyde and stained with crystal violet.

\section{Plaque reduction assay}

200 pfu of each SARS-CoV-2 strain (100 ul) was incubated with two-fold serial dilutions of sera $(100 \mathrm{ul})$ for $1 \mathrm{~h}$ at room temperature. 100 ul of antibody-virus mixtures containing $100 \mathrm{pfu}$ of SARS-CoV-2 were inoculated into Vero-E6 cells to perform the plaque assay. At $48 \mathrm{~h}$ post-infection, plaques were visualized and counted.

\section{Transcriptome analysis}

$1 \mu \mathrm{g}$ of total RNA was enriched for polyadenylated RNA species and prepared for short-read next-generation sequencing using the TruSeq Stranded mRNA Library Prep Kit (Illumina) according to the manufacturer's instructions. Sequencing libraries were sequenced on an Illumina NextSeq 500 platform. Fastq files were generated using bcl2fastq (Illumina) and aligned to the Syrian golden hamster genome (MesAur 1.0, ensembl) using the RNA-Seq Alignment application (Basespace, Illumina). Differential gene expression was determined using the DESeq2 pipeline (Love MI, Huber W, Anders S (2014). "Moderated estimation of fold change and dispersion for RNA-seq data with DESeq2." Genome Biology, 15, 550. doi: 10.1186/s13059-014-0550-8). All genes with a p-adjusted value (p-adj) $<0.1$ were classified as differentially expressed genes. Number of reads mapping to the viral genome (GenBank: MN985325.1) was performed using bowtie2 (65). Gene set enrichment analysis was performed with GSEA java application GSEA_4.1.0 (made available by the Broad Institute and UC San Diego) (https://www.nature.com/articles/ng1180). GSEA was conducted as a pre-ranked analysis using a ranking statistic of $\log 10$ (p-value)/sign(log2FoldChange). Gene sets used for analysis were part of Hallmark and curated human phenotype and gene ontology gene sets maintained as part of MSigDB (v7.4). All visualizations of RNA-sequencing differential expression data were created in R using ggplot2 and gplots packages. Gene set enrichment plots were adapted from VisualizeRNAseq (https://github.com/GryderArt/VisualizeRNAseq).

\section{qRT-PCR}

RNA was reverse transcribed into cDNA using oligo-dT primers with Superscript II Reverse transcriptase (ThermoFisher). qPCR reaction was performed using primers specific for beta-actin, ISG15, IRF7, Cxcl10 or CCL5 (18) with KAPA SYBR Fast qPCR Master Mix (KAPA Biosystems) on Light Cycler 480 Instrument II (Roche). Delta-delta-cycle threshold was determined relative to non-infected samples.

Immune profiling in Syrian golden hamsters by Flow Cytometry

Lung cells were collected upon perfusion with $30 \mathrm{ml}$ PBS to avoid contamination of lymphocytes from the blood. After collection, lungs were either chopped in small pieces by sessors or dissociated by Miltenyi Gentle MACS with the lung 
dissociation Kit protocol. Dissociated lungs were incubated in $37^{\circ} \mathrm{C}$ for $30 \mathrm{~min}$ with $2 \mathrm{ml}$ Collagenase $(1 \mathrm{mg} / \mathrm{ml}) / D N a s e$ $(0.5 \mathrm{mg} / \mathrm{ml})$ and passed through $70 \mathrm{~mm}$ nylon mesh (FALCON \#352350). For total lymphoid cell count and SARSCoV-2-specific CD4+ $\mathrm{T}$ cell detection assay, homogenized lungs were further subjected to Ficol separation (1200Gx20min). For FACS analysis, cells were stained with anti-CD4 (GK1.5; Biolegend), anti-MHCll (14-4-4s; ThermoFisher), anti-CXCR5 (L138D7; Biolegened), anti-CXCR3 (CXCR3-173: BD Biosciences), anti-Syrian golden hamster IgG2 (G192-3; BD Biosciences), anti-Syrian golden hamster IgG (Invitrogen) extra cellularly. For intranuclear staining, cells were fixed for $30 \mathrm{~min}$ at $4^{\circ} \mathrm{C}$ with Fix Buffer I (BD Biosciences) and were then incubated for overnight at $4^{\circ} \mathrm{C}$ with anti-Ki67 (16A8; Biolegend), anti-Bcl6 (K112-91; BD Biosciences), anti-CD3 (CD3-12; BioRad), anti-FoxP3 (FJK-16s; ThermoFisher) in Perm/Wash Buffer (BD Biosciences). AntiIRF4 (3E4; Biolegend) were used intra cellular for SARS-CoV2 -specific CD4+ T cells. All samples were incubated with LIVE/DEAD Fixable yellow (Invitrogen) to exclude dead cells from the analysis. Cells were acquired on a Attune (ThermoFisher). Expression of each molecule was assessed with FlowJo software (TreeStar).

\section{Anti-RBD hamster IgG ELISA}

The ELISA protocol was adapted from a previously established protocol (Amanat et al., 2020). 96-well plates (Immulon 4 HBX, Thermo Fisher) were coated with $50 \mathrm{ml}$ of 2 $\mathrm{mg} / \mathrm{ml}$ recombinant $\mathrm{RBD}$ in $\mathrm{PBS}$ at $4 \mathrm{C}$ overnight. After overnight incubation, the coating solutions were removed, and the plates were blocked with $100 \mathrm{ml}$ of $3 \%$ non-fat milk (americanBio) prepared in $0.1 \%$ Tween 20 containing PBS (PBS-T) for 1 hour at room temperature. To reduce the risk of containing live virus, serum samples were heated 1 hour for $56 \mathrm{C}$ before use and was handled in a BSL-3 facility. Serial dilution of serum samples and dilution of secondary antibody was done in 1\% non-fat milk prepared in PBS-T. After blocking, solutions were removed and $100 \mathrm{ml}$ of diluted serum was added following 2 hours incubation at room temperature. After the solutions were removed, the wells were washed with $250 \mathrm{ml}$ PBS-T three times. $100 \mathrm{ml}$ of 1:7500 diluted anti-Syrian hamster IgG HRP (ThermoFisher) secondary antibody was added and incubated for 1 hour at room temperature. After the solutions were removed, the wells were washed with $250 \mathrm{ml}$ PBS-T three times. Once the wells were completely dry, $100 \mathrm{~mL}$ of SIG- MAFAST o-phenylenediamine dihydrochloride (Millipore Sigma) solution was added and the reaction was stopped with $30 \mathrm{ml}$ of $3 \mathrm{M} \mathrm{HCl}$. The optical density at $490 \mathrm{~nm}$ was measured and the concentrations of the antibody were analyzed by area under curve (AUC) using Prism 8 (GraphPad).

\section{Antigen-specific CDA+ $T$ cells and $B$ cell detection as-} say
To identify SARS-CoV-2-specific CD4+ T cells, ficol separated cells collected from either lungs, PBMCs, mLNs, or spleens were rested overnight $37^{\circ} \mathrm{C}$ in non-serum media (XVIVOTM 15; Lonza) with the concentration at $1 \times 10^{6}$ cells per well in a 96 well U bottom plate (TPP; 92097). Cells were further cultured 24 hours $37^{\circ} \mathrm{C}$ with the presence of SARS-CoV2 Spike (S), nucleocapsid (N) and matrix (M) peptide mix (1 $\mu \mathrm{g} / \mathrm{ml}$ each; Gene script). Staphylococcal enterotoxin B (SEB; $1 \mu \mathrm{g} / \mathrm{mL}$ ) stimulation were used as a positive control and DMSO was used as a negative control. After stimulation, cells were collected and further processed for FACS analysis.

To identify SARS-CoV-2 S-specific B cells, recombinant SARS-CoV-2 S protein were biotin-labeled (EZ-Link SulfoNHS-LC-Biotinylation kit, ThermoFisher). Ficol separated cells collected from either lungs, PBMCs, mLNs, or spleens were stained with biotin labeled SARS-CoV-2 S protein with the combination of antibodies. Biotin was further detected by streptavidin-BV786 and -BV650.

\section{Adoptive transfer assay}

To identify transferred cells, lymphoid cells from the lungs and spleens were labeled with CTV (Cell trance violet cell proliferation kit; ThermoFisher). The labeled cells were further transferred intravenously $2 \times 10^{6}$ cell/hamster. After 4 days, lungs, PBMCs, and spleens were collected to detect CTV by FACS. For total cell transfer from SARS-CoV-2WA recovered hamsters, lymphoid cells from the SARS-CoV-2WA recovered hamster lungs, PBMCs, and spleens were collected. The cells were further transferred intravenously $5 \times 10^{7}$ cell/hamster. After one day cell transfer, hamsters were infected by SARS-CoV-2WA accordingly. For T cell enriched cell transfer experiment from SARS-CoV-2WA recovered hamsters, lymphoid cells from the SARS-CoV-2WA recovered hamster lungs, PBMCs, and spleens were collected. MHCll+ cells were depleted with the combination of Biotin-antiMHCll antibody (1.2 $\mathrm{\mu g} / \mathrm{mL}$; Invitrogen; MA5-17761), Biotinanti-hamster IgG (1.2 $\mu \mathrm{g} / \mathrm{mL}$; Biolegend; 405601), in lab biotin labeled anti-hamster IgM $(1.2 \mu \mathrm{g} / \mathrm{mL}$; Rockland; 107-4107) after adjusting the cells to $1 \times 10^{8} \mathrm{cell} / \mathrm{ml}$. Cells were further processed with Biotin Positive Selection Kit ll (STEMCELL) and remained cells were used as CD3+ T cell enriched cells. For the cell transfer, $2 \times 10^{6}$ cell/hamster for the lung, $2 \times 10^{7}$ cell/hamster for PBMCs and spleens were transferred intravenously. After one day cell transfer, hamsters were infected by SARS-CoV-2WA accordingly.

\section{Statistics}

The significance of the difference between groups in the experiments were evaluated by two- tailed paired $t$ test by Prism (GraphPad) software. A value of $\mathrm{p}<0.05$ was considered significant.

\section{SUPPLEMENTARY MATERIALS}

www.science.org/doi/10.1126/sciimmunol.abm3131 Figs. S1 to S6 
Table S1

\section{REFERENCES AND NOTES}

1. S. Koyama, K. J. Ishii, C. Coban, S. Akira, Innate immune response to viral infection. Cytokine 43, 336-341 (2008). doi:10.1016/j.cyto.2008.07.009 Medline

2. A. Park, A. Iwasaki, Type I and Type III Interferons - Induction, Signaling, Evasion, and Application to Combat COVID-19. Cell Host Microbe 27, 870-878 (2020). doi:10.1016/i.chom.2020.05.008 Medline

3. A. Iwasaki, A virological view of innate immune recognition. Annu. Rev. Microbiol. 66, 177-196 (2012). doi:10.1146/annurev-micro-092611-150203 Medline

4. C. A. Janeway Jr., R. Medzhitov, Innate immune recognition. Annu. Rev. Immunol. 20, 197-216 (2002). doi:10.1146/annurev.immunol.20.083001.084359 Medline

5. T. Maniatis, J. V. Falvo, T. H. Kim, T. K. Kim, C. H. Lin, B. S. Parekh, M. G. Wathelet, Structure and function of the interferon-beta enhanceosome. Cold Spring Harb. Symp. Quant. Biol. 63, 609-620 (1998). doi:10.1101/sqb.1998.63.609 Medline

6. H. M. Lazear, J. W. Schoggins, M. S. Diamond, Shared and Distinct Functions of Type I and Type III Interferons. Immunity 50, 907-923 (2019). doi:10.1016/i.immuni.2019.03.025 Medline

7. J. W. Schoggins, S. J. Wilson, M. Panis, M. Y. Murphy, C. T. Jones, P. Bieniasz, C. M Rice, A diverse range of gene products are effectors of the type I interferon antiviral response. Nature 472, 481-485 (2011). doi:10.1038/nature09907 Medline

8. D. Bogunovic, M. Byun, L. A. Durfee, A. Abhyankar, O. Sanal, D. Mansouri, S. Salem, I. Radovanovic, A. V. Grant, P. Adimi, N. Mansouri, S. Okada, V. L. Bryant, X. F. Kong, A. Kreins, M. M. Velez, B. Boisson, S. Khalilzadeh, U. Ozcelik, I. A. Darazam, J. W. Schoggins, C. M. Rice, S. Al-Muhsen, M. Behr, G. Vogt, A. Puel, J. Bustamante, P. Gros, J. M. Huibregtse, L. Abel, S. Boisson-Dupuis, J. L. Casanova, Mycobacterial disease and impaired IFN-Y immunity in humans with inherited ISG15 deficiency. Science 337, 1684-1688 (2012). doi:10.1126/science.1224026 Medline

9. K. Honda, H. Yanai, H. Negishi, M. Asagiri, M. Sato, T. Mizutani, N. Shimada, Y. Ohba, A. Takaoka, N. Yoshida, T. Taniguchi, IRF-7 is the master regulator of typeinterferon-dependent immune responses. Nature 434, 772-777 (2005). doi:10.1038/nature03464 Medline

10. A. E. Proudfoot, Chemokine receptors: Multifaceted therapeutic targets. Nat. Rev Immunol. 2, 106-115 (2002). doi:10.1038/nri722 Medline

11. C. L. Sokol, A. D. Luster, The chemokine system in innate immunity. Cold Spring Harb. Perspect. Biol. 7, a016303 (2015). doi:10.1101/cshperspect.a016303 Medline

12. F. Coperchini, L. Chiovato, L. Croce, F. Magri, M. Rotondi, The cytokine storm in COVID-19: An overview of the involvement of the chemokine/chemokine-receptor system. Cytokine Growth Factor Rev. 53, 25-32 (2020). doi:10.1016/i.cytogfr.2020.05.003 Medline

13. J. Talon, C. M. Horvath, R. Polley, C. F. Basler, T. Muster, P. Palese, A. GarcíaSastre, Activation of interferon regulatory factor 3 is inhibited by the influenza $A$ virus NS1 protein. J. Virol. 74, 7989-7996 (2000). doi:10.1128/JVL.74.17.79897996.2000 Medline

14. D. Blanco-Melo, B. E. Nilsson-Payant, W. C. Liu, S. Uhl, D. Hoagland, R. Møller, T. X. Jordan, K. Oishi, M. Panis, D. Sachs, T. T. Wang, R. E. Schwartz, J. K. Lim, R. A Albrecht, B. R. tenOever, Imbalanced Host Response to SARS-CoV-2 Drives Development of COVID-19. Cell 181, 1036-1045.e9 (2020). doi:10.1016/i.cell.2020.04.026 Medline

15. A. Z. Eriksen, R. Møller, B. Makovoz, S. A. Uhl, B. R. tenOever, T. A. Blenkinsop SARS-CoV-2 infects human adult donor eyes and hESC-derived ocular epithelium. Cell Stem Cell 28, 1205-1220.e7 (2021). doi:10.1016/j.stem.2021.04.028 Medline

16. C. Lucas, P. Wong, J. Klein, T. B. R. Castro, J. Silva, M. Sundaram, M. K. Ellingson, T. Mao, J. E. Oh, B. Israelow, T. Takahashi, M. Tokuyama, P. Lu, A. Venkataraman, A. Park, S. Mohanty, H. Wang, A. L. Wyllie, C. B. F. Vogels, R. Earnest, S. Lapidus, I. M. Ott, A. J. Moore, M. C. Muenker, J. B. Fournier, M. Campbell, C. D. Odio, A. Casanovas-Massana, R. Herbst, A. C. Shaw, R. Medzhitov, W. L. Schulz, N. D. Grubaugh, C. Dela Cruz, S. Farhadian, A. I. Ko, S. B. Omer, A. Iwasaki; Yale IMPACT Team, Longitudinal analyses reveal immunological misfiring in severe COVID-19. Nature 584, 463-469 (2020). doi:10.1038/s41586-020-2588-y Medline

17. C. Lucas, J. Klein, M. E. Sundaram, F. Liu, P. Wong, J. Silva, T. Mao, J. E. Oh, S. Mohanty, J. Huang, M. Tokuyama, P. Lu, A. Venkataraman, A. Park, B. Israelow, C. B. F. Vogels, M. C. Muenker, C. H. Chang, A. Casanovas-Massana, A. J. Moore, J.
Zell, J. B. Fournier, I. R. T. Yale, A. L. Wyllie, M. Campbell, A. I. Lee, H. J. Chun, N. D. Grubaugh, W. L. Schulz, S. Farhadian, C. Dela Cruz, A. M. Ring, A. C. Shaw, A. V. Wisnewski, I. Yildirim, A. I. Ko, S. B. Omer, A. Iwasaki, Delayed production of neutralizing antibodies correlates with fatal COVID-19. Nat. Med. (2021).

18. D. A. Hoagland, R. Møller, S. A. Uhl, K. Oishi, J. Frere, I. Golynker, S. Horiuchi, M. Panis, D. Blanco-Melo, D. Sachs, K. Arkun, J. K. Lim, B. R. tenOever, Leveraging the antiviral type I interferon system as a first line of defense against SARS-CoV2 pathogenicity. Immunity 54, 557-570.e5 (2021) doi:10.1016/i.immuni.2021.01.017 Medline

19. A. J. Sant, A. T. DiPiazza, J. L. Nayak, A. Rattan, K. A. Richards, CD4 T cells in protection from influenza virus: Viral antigen specificity and functional potential. Immunol. Rev. 284, 91-105 (2018). doi:10.1111/imr.12662 Medline

20. S. van de Wall, V. P. Badovinac, J. T. Harty, Influenza-Specific Lung-Resident Memory CD8 ${ }^{+}$T Cells. Cold Spring Harb. Perspect. Biol. 13, a037978 (2021). doi:10.1101/cshperspect.a037978 Medline

21. T. Inoue, I. Moran, R. Shinnakasu, T. G. Phan, T. Kurosaki, Generation of memory B cells and their reactivation. Immunol. Rev. 283, 138-149 (2018). doi:10.1111/imr.12640 Medline

22. K. Miyauchi, Helper T Cell Responses to Respiratory Viruses in the Lung: Development, Virus Suppression, and Pathogenesis. Viral Immunol. 30, 421-430 (2017). doi:10.1089/vim.2017.0018 Medline

23. A. Sette, S. Crotty, Adaptive immunity to SARS-CoV-2 and COVID-19. Cell 184, 861-880 (2021). doi:10.1016/j.cell.2021.01.007 Medline

24. J. M. Dan, J. Mateus, Y. Kato, K. M. Hastie, E. D. Yu, C. E. Faliti, A. Grifoni, S. I. Ramirez, S. Haupt, A. Frazier, C. Nakao, V. Rayaprolu, S. A. Rawlings, B. Peters, F. Krammer, V. Simon, E. O. Saphire, D. M. Smith, D. Weiskopf, A. Sette, S. Crotty, Immunological memory to SARS-CoV-2 assessed for up to 8 months after infection. Science 371, eabf4063 (2021). doi:10.1126/science.abf4063 Medline

25. Z. Wang, F. Schmidt, Y. Weisblum, F. Muecksch, C. O. Barnes, S. Finkin, D. Schaefer-Babajew, M. Cipolla, C. Gaebler, J. A. Lieberman, T. Y. Oliveira, Z. Yang, M. E. Abernathy, K. E. Huey-Tubman, A. Hurley, M. Turroja, K. A. West, K. Gordon, K. G. Millard, V. Ramos, J. Da Silva, J. Xu, R. A. Colbert, R. Patel, J. Dizon, C. UnsonO'Brien, I. Shimeliovich, A. Gazumyan, M. Caskey, P. J. Bjorkman, R. Casellas, T. Hatziioannou, P. D. Bieniasz, M. C. Nussenzweig, mRNA vaccine-elicited antibodies to SARS-CoV-2 and circulating variants. Nature 592, 616-622 (2021). doi:10.1038/s41586-021-03324-6 Medline

26. P. Jalkanen, P. Kolehmainen, H. K. Häkkinen, M. Huttunen, P. A. Tähtinen, R. Lundberg, S. Maljanen, A. Reinholm, S. Tauriainen, S. H. Pakkanen, I. Levonen, A. Nousiainen, T. Miller, H. Välimaa, L. Ivaska, A. Pasternack, R. Naves, O. Ritvos, P. Österlund, S. Kuivanen, T. Smura, J. Hepojoki, O. Vapalahti, J. Lempainen, L. Kakkola, A. Kantele, I. Julkunen, COVID-19 mRNA vaccine induced antibody responses against three SARS-CoV-2 variants. Nat. Commun. 12, 3991 (2021). doi:10.1038/s41467-021-24285-4 Medline

27. M. McCallum, J. Bassi, A. De Marco, A. Chen, A. C. Walls, J. Di lulio, M. A. Tortorici, M. J. Navarro, C. Silacci-Fregni, C. Saliba, K. R. Sprouse, M. Agostini, D. Pinto, K. Culap, S. Bianchi, S. Jaconi, E. Cameroni, J. E. Bowen, S. W. Tilles, M. S. Pizzuto, S. B. Guastalla, G. Bona, A. F. Pellanda, C. Garzoni, W. C. Van Voorhis, L. E. Rosen, G. Snell, A. Telenti, H. W. Virgin, L. Piccoli, D. Corti, D. Veesler, SARS-CoV-2 immune evasion by the B.1.427/B.1.429 variant of concern. Science 373, 648654 (2021). doi:10.1126/science.abi7994 Medline

28. S. F. Sia, L. M. Yan, A. W. H. Chin, K. Fung, K. T. Choy, A. Y. L. Wong, P. Kaewpreedee, R. A. P. M. Perera, L. L. M. Poon, J. M. Nicholls, M. Peiris, H. L. Yen, Pathogenesis and transmission of SARS-CoV-2 in golden hamsters. Nature 583 , 834-838 (2020). doi:10.1038/s41586-020-2342-5 Medline

29. N. Osterrieder, L. D. Bertzbach, K. Dietert, A. Abdelgawad, D. Vladimirova, D. Kunec, D. Hoffmann, M. Beer, A. D. Gruber, J. Trimpert, Age-Dependent Progression of SARS-CoV-2 Infection in Syrian Hamsters. Viruses 12, 779 (2020). doi:10.3390/v12070779 Medline

30. M. Imai, K. Iwatsuki-Horimoto, M. Hatta, S. Loeber, P. J. Halfmann, N. Nakajima, T. Watanabe, M. Ujie, K. Takahashi, M. Ito, S. Yamada, S. Fan, S. Chiba, M. Kuroda, L. Guan, K. Takada, T. Armbrust, A. Balogh, Y. Furusawa, M. Okuda, H. Ueki, A. Yasuhara, Y. Sakai-Tagawa, T. J. S. Lopes, M. Kiso, S. Yamayoshi, N. Kinoshita, N. Ohmagari, S. I. Hattori, M. Takeda, H. Mitsuya, F. Krammer, T. Suzuki, Y. Kawaoka, Syrian hamsters as a small animal model for SARS-CoV-2 infection and countermeasure development. Proc. Natl. Acad. Sci. U.S.A. 117, 16587-16595 


\section{(2020). doi:10.1073/pnas.2009799117 Medline}

31. K. Rosenke, K. Meade-White, M. Letko, C. Clancy, F. Hansen, Y. Liu, A. Okumura, T. L. Tang-Huau, R. Li, G. Saturday, F. Feldmann, D. Scott, Z. Wang, V. Munster, M. A. Jarvis, H. Feldmann, Defining the Syrian hamster as a highly susceptible preclinical model for SARS-CoV-2 infection. Emerg. Microbes Infect. 9, 26732684 (2020). doi:10.1080/22221751.2020.1858177 Medline

32. K. Iwatsuki-Horimoto, N. Nakajima, Y. Ichiko, Y. Sakai-Tagawa, T. Noda, H. Hasegawa, Y. Kawaoka, Syrian Hamster as an Animal Model for the Study of Human Influenza Virus Infection. J. Virol. 92, ・. (2018). doi:10.1128/JVl.0169317 Medline

33. C. D. Hammerbeck, J. W. Hooper, T cells are not required for pathogenesis in the Syrian hamster model of hantavirus pulmonary syndrome. J. Virol. 85, 99299944 (2011). doi:10.1128/JVI.05356-11 Medline

34. Y. Nakornpakdee, R. W. Sermswan, S. Maneewatchararangsri, S. Wongratanacheewin, Hamster IFN- $\gamma+\mathrm{CD} 4+$ and IL-4+CD4+ T cell responses against leptospires are significantly higher than those of mice. Asian Pac. J. Allergy Immunol. 36, 265-272 (2018). Medline

35. C. Kaewraemruaen, R. W. Sermswan, S. Wongratanacheewin, Induction of regulatory T cells by Opisthorchis viverrini. Parasite Immunol. 38, 688-697 (2016). doi:10.1111/pim.12358 Medline

36. K. Miyauchi, A. Sugimoto-Ishige, Y. Harada, Y. Adachi, Y. Usami, T. Kaji, K. Inoue, H. Hasegawa, T. Watanabe, A. Hijikata, S. Fukuyama, T. Maemura, M. OkadaHatakeyama, O. Ohara, Y. Kawaoka, Y. Takahashi, T. Takemori, M. Kubo, Protective neutralizing influenza antibody response in the absence of T follicular helper cells. Nat. Immunol. 17, 1447-1458 (2016). doi:10.1038/ni.3563 Medline

37. J. S. Hale, B. Youngblood, D. R. Latner, A. U. Mohammed, L. Ye, R. S. Akondy, T. Wu, S. S. Iyer, R. Ahmed, Distinct memory CD4+ T cells with commitment to T follicular helper- and T helper 1-cell lineages are generated after acute viral infection. Immunity 38, 805-817 (2013). doi:10.1016/i.immuni.2013.02.020 Medline

38. R. J. Betts, N. Prabhu, A. W. Ho, F. C. Lew, P. E. Hutchinson, O. Rotzschke, P. A. Macary, D. M. Kemeny, Influenza A virus infection results in a robust, antigenresponsive, and widely disseminated Foxp3+ regulatory T cell response. J. Virol. 86, 2817-2825 (2012). doi:10.1128/JVI.05685-11 Medline

39. A. G. Levine, A. Mendoza, S. Hemmers, B. Moltedo, R. E. Niec, M. Schizas, B. E. Hoyos, E. V. Putintseva, A. Chaudhry, S. Dikiy, S. Fujisawa, D. M. Chudakov, P. M. Treuting, A. Y. Rudensky, Stability and function of regulatory T cells expressing the transcription factor T-bet. Nature 546, 421-425 (2017). doi:10.1038/nature22360 Medline

40. H. D. Hickman, G. V. Reynoso, B. F. Ngudiankama, S. S. Cush, J. Gibbs, J. R. Bennink, J. W. Yewdell, CXCR3 chemokine receptor enables local CD8(+) T cell migration for the destruction of virus-infected cells. Immunity 42, 524-537 (2015). doi:10.1016/i.immuni.2015.02.009 Medline

41. D. Mathew, J. R. Giles, A. E. Baxter, D. A. Oldridge, A. R. Greenplate, J. E. Wu, C. Alanio, L. Kuri-Cervantes, M. B. Pampena, K. D'Andrea, S. Manne, Z. Chen, Y. J. Huang, J. P. Reilly, A. R. Weisman, C. A. G. Ittner, O. Kuthuru, J. Dougherty, K. Nzingha, N. Han, J. Kim, A. Pattekar, E. C. Goodwin, E. M. Anderson, M. E. Weirick, S. Gouma, C. P. Arevalo, M. J. Bolton, F. Chen, S. F. Lacey, H. Ramage, S. Cherry, S. E. Hensley, S. A. Apostolidis, A. C. Huang, L. A. Vella, M. R. Betts, N. J. Meyer, E. J. Wherry; UPenn COVID Processing Unit, Deep immune profiling of COVID-19 patients reveals distinct immunotypes with therapeutic implications. Science 369, eabc8511 (2020). doi:10.1126/science.abc8511 Medline

42. J. Braun, L. Loyal, M. Frentsch, D. Wendisch, P. Georg, F. Kurth, S. Hippenstiel, M. Dingeldey, B. Kruse, F. Fauchere, E. Baysal, M. Mangold, L. Henze, R. Lauster, M. A. Mall, K. Beyer, J. Röhmel, S. Voigt, J. Schmitz, S. Miltenyi, I. Demuth, M. A. Müller, A. Hocke, M. Witzenrath, N. Suttorp, F. Kern, U. Reimer, H. Wenschuh, C. Drosten, V. M. Corman, C. Giesecke-Thiel, L. E. Sander, A. Thiel, SARS-CoV-2reactive T cells in healthy donors and patients with COVID-19. Nature 587, 270274 (2020). doi:10.1038/s41586-020-2598-9 Medline

43. H. Wu, A. Witzl, H. Ueno, Assessment of TCR signal strength of antigen-specific memory CD8 ${ }^{+} \mathrm{T}$ cells in human blood. Blood Adv. 3, 2153-2163 (2019). doi:10.1182/bloodadvances.2019000292 Medline

44. M. M. L. Poon, K. Rybkina, Y. Kato, M. Kubota, R. Matsumoto, N. I. Bloom, Z. Zhang, K. M. Hastie, A. Grifoni, D. Weiskopf, S. B. Wells, B. B. Ural, N. Lam, P. A. Szabo, P. Dogra, Y. S. Lee, J. I. Gray, M. C. Bradley, M. A. Brusko, T. M. Brusko, E. O. Saphire,
T. J. Connors, A. Sette, S. Crotty, D. L. Farber, SARS-CoV-2 infection generates tissue-localized immunological memory in humans. Sci. Immunol. eabl9105 (2021). doi:10.1126/sciimmunol.abl9105 Medline

45. R. J. Cox, K. A. Brokstad, Not just antibodies: $B$ cells and T cells mediate immunity to COVID-19. Nat. Rev. Immunol. 20, 581-582 (2020). doi:10.1038/s41577-02000436-4 Medline

46. J. Grau-Expósito, N. Sánchez-Gaona, N. Massana, M. Suppi, A. Astorga-Gamaza, D. Perea, J. Rosado, A. Falcó, C. Kirkegaard, A. Torrella, B. Planas, J. Navarro, P. Suanzes, D. Álvarez-Sierra, A. Ayora, I. Sansano, J. Esperalba, C. Andrés, A. Antón, S. Ramón Y Cajal, B. Almirante, R. Pujol-Borrell, V. Falcó, J. Burgos, M. J. Buzón, $M$. Genescà, Peripheral and lung resident memory T cell responses against SARSCoV-2. Nat. Commun. 12, 3010 (2021). doi:10.1038/s41467-021-23333-3 Medline

47. S. Yamayoshi, A. Yasuhara, M. Ito, O. Akasaka, M. Nakamura, I. Nakachi, M. Koga, K. Mitamura, K. Yagi, K. Maeda, H. Kato, M. Nojima, D. Pattinson, T. Ogura, R. Baba, K. Fujita, H. Nagai, S. Yamamoto, M. Saito, E. Adachi, J. Ochi, S. I. Hattori, T. Suzuki, Y. Miyazato, S. Chiba, M. Okuda, J. Murakami, T. Hamabata, K. IwatsukiHorimoto, H. Nakajima, H. Mitsuya, N. Omagari, N. Sugaya, H. Yotsuyanagi, Y. Kawaoka, Antibody titers against SARS-CoV-2 decline, but do not disappear for several months. EClinicalMedicine 32, $100734 \quad$ (2021) doi:10.1016/i.eclinm.2021.100734 Medline

48. G. T. Campbell, A. C. Gore, M. J. Woller, C. A. Blake, Adenohypophysial allografts releasing prolactin decrease prolactin mRNA concentration in the host hamster's adenohypophysis in situ. Neuroendocrinology 63, 430-436 (1996). doi:10.1159/000127068 Medline

49. G. L. Wang, Z. Y. Wang, L. J. Duan, Q. C. Meng, M. D. Jiang, J. Cao, L. Yao, K. L. Zhu, W. C. Cao, M. J. Ma, Susceptibility of Circulating SARS-CoV-2 Variants to Neutralization. N. Engl. J. Med. 384, 2354-2356 (2021) doi:10.1056/NEJMc2103022 Medline

50. T. A. Bates, H. C. Leier, Z. L. Lyski, S. K. McBride, F. J. Coulter, J. B. Weinstein, J. R. Goodman, Z. Lu, S. A. R. Siegel, P. Sullivan, M. Strnad, A. E. Brunton, D. X. Lee, M. E. Curlin, W. B. Messer, F. G. Tafesse, Neutralization of SARS-CoV-2 variants by convalescent and vaccinated serum. medRxiv, (2021).

51. R. E. Chen, X. Zhang, J. B. Case, E. S. Winkler, Y. Liu, L. A. VanBlargan, J. Liu, J. M. Errico, X. Xie, N. Suryadevara, P. Gilchuk, S. J. Zost, S. Tahan, L. Droit, J. S. Turner W. Kim, A. J. Schmitz, M. Thapa, D. Wang, A. C. M. Boon, R. M. Presti, J. A. O'Halloran, A. H. J. Kim, P. Deepak, D. Pinto, D. H. Fremont, J. E. Crowe Jr., D. Corti, H. W. Virgin, A. H. Ellebedy, P. Y. Shi, M. S. Diamond, Resistance of SARS-CoV-2 variants to neutralization by monoclonal and serum-derived polyclonal antibodies. Nat. Med. 27, 717-726 (2021). doi:10.1038/s41591-021-01294-w Medline

52. M. Diamond, R. Chen, X. Xie, J. Case, X. Zhang, L. VanBlargan, Y. Liu, J. Liu, J. Errico, E. Winkler, N. Suryadevara, S. Tahan, J. Turner, W. Kim, A. Schmitz, M. Thapa, D. Wang, A. Boon, D. Pinto, R. Presti, J. O'Halloran, A. Kim, P. Deepak, D. Fremont, D. Corti, H. Virgin, J. Crowe, L. Droit, A. Ellebedy, P. Y. Shi, P. Gilchuk, SARS-CoV-2 variants show resistance to neutralization by many monoclonal and serum-derived polyclonal antibodies. Res Sq, (2021).

53. A. Muik, A. K. Wallisch, B. Sänger, K. A. Swanson, J. Mühl, W. Chen, H. Cai, D. Maurus, R. Sarkar, Ö. Türeci, P. R. Dormitzer, U. Şahin, Neutralization of SARSCoV-2 lineage B.1.1.7 pseudovirus by BNT162b2 vaccine-elicited human sera. Science 371, 1152-1153 (2021). doi:10.1126/science.abg6105 Medline

54. C. K. Wibmer, F. Ayres, T. Hermanus, M. Madzivhandila, P. Kgagudi, B. Oosthuysen, B. E. Lambson, T. de Oliveira, M. Vermeulen, K. van der Berg, T. Rossouw, M. Boswell, V. Ueckermann, S. Meiring, A. von Gottberg, C. Cohen, L. Morris, J. N. Bhiman, P. L. Moore, SARS-CoV-2 501Y.V2 escapes neutralization by South African COVID-19 donor plasma. Nat. Med. 27, 622-625 (2021) doi:10.1038/s41591-021-01285-x Medline

55. M. Shi, X. D. Lin, X. Chen, J. H. Tian, L. J. Chen, K. Li, W. Wang, J. S. Eden, J. J. Shen, L. Liu, E. C. Holmes, Y. Z. Zhang, The evolutionary history of vertebrate RNA viruses. Nature 556, 197-202 (2018). doi:10.1038/s41586-018-0012-7 Medline

56. D. Geers, M. C. Shamier, S. Bogers, G. den Hartog, L. Gommers, N. N. Nieuwkoop, K. S. Schmitz, L. C. Rijsbergen, J. A. T. van Osch, E. Dijkhuizen, G. Smits, A. Comvalius, D. van Mourik, T. G. Caniels, M. J. van Gils, R. W. Sanders, B. B. Oude Munnink, R. Molenkamp, H. J. de Jager, B. L. Haagmans, R. L. de Swart, M. P. G. Koopmans, R. S. van Binnendijk, R. D. de Vries, C. H. GeurtsvanKessel, SARS-CoV2 variants of concern partially escape humoral but not T-cell responses in COVID- 
19 convalescent donors and vaccinees. Sci. Immunol. 6, eabj1750 (2021). doi:10.1126/sciimmunol.abj1750 Medline

57. B. Israelow, T. Mao, J. Klein, E. Song, B. Menasche, S. B. Omer, A. Iwasaki, Adaptive immune determinants of viral clearance and protection in mouse models of SARSCoV-2. bioRxiv, (2021)

58. K. McMahan, J. Yu, N. B. Mercado, C. Loos, L. H. Tostanoski, A. Chandrashekar, J. Liu, L. Peter, C. Atyeo, A. Zhu, E. A. Bondzie, G. Dagotto, M. S. Gebre, C. JacobDolan, Z. Li, F. Nampanya, S. Patel, L. Pessaint, A. Van Ry, K. Blade, J. YalleyOgunro, M. Cabus, R. Brown, A. Cook, E. Teow, H. Andersen, M. G. Lewis, D. A. Lauffenburger, G. Alter, D. H. Barouch, Correlates of protection against SARSCoV-2 in rhesus macaques. Nature 590, 630-634 (2021). doi:10.1038/s41586020-03041-6 Medline

59. J. R. Teijaro, D. Turner, Q. Pham, E. J. Wherry, L. Lefrançois, D. L. Farber, Cutting edge: Tissue-retentive lung memory CD4 T cells mediate optimal protection to respiratory virus infection. J. Immunol. 187, 5510-5514 (2011). doi:10.4049/iimmunol.1102243 Medline

60. K. B. Pruner, M. Pepper, Local memory CD4 T cell niches in respiratory viral infection. J. Exp. Med. 218, e20201733 (2021). doi:10.1084/jem.20201733 Medline

61. A. S. V. Shah, C. Gribben, J. Bishop, P. Hanlon, D. Caldwell, R. Wood, M. Reid, J. McMenamin, D. Goldberg, D. Stockton, S. Hutchinson, C. Robertson, P. M. McKeigue, H. M. Colhoun, D. A. McAllister, Effect of Vaccination on Transmission of SARS-CoV-2. N. Engl. J. Med. NEJMc2106757 (2021). doi:10.1056/NEJMc2106757 Medline

62. R. J. Harris, J. A. Hall, A. Zaidi, N. J. Andrews, J. K. Dunbar, G. Dabrera, Effect of Vaccination on Household Transmission of SARS-CoV-2 in England. N. Engl. J. Med. 385, 759-760 (2021). doi:10.1056/NEJMc2107717 Medline

63. A. Chandrashekar, J. Liu, J. Yu, K. McMahan, L. H. Tostanoski, C. Jacob-Dolan, N. B. Mercado, T. Anioke, A. Chang, S. Gardner, V. M. Giffin, D. L. Hope, F. Nampanya, S. Patel, O. Sanborn, D. Sellers, H. Wan, A. J. Martinot, J. J. Baczenas, S. L. O'Connor, L. Pessaint, D. Valentin, B. Espina, L. Wattay, M. G. Ferrari, R. Brown, A. Cook, D. Bueno-Wilkerson, E. Teow, H. Andersen, M. G. Lewis, D. H. Barouch, Prior infection with SARS-CoV-2 WA1/2020 partially protects rhesus macaques against re-infection with B.1.1.7 and B.1.351 variants. Sci. Transl. Med. eabj2641 (2021). doi:10.1126/scitransImed.abj2641 Medline
64. J. Y. Lisa H. Tostanoski, Noe B. Mercado, Katherine McMahan, Catherine JacobDolan, Amanda J. Martinot, Cesar Piedra-Mora, Tochi Anioke, Aiquan Chang, Victoria M. Giffin, David L. Hope, Huahua Wan, Esther A. Bondzie, Shant H. Mahrokhian, Linda M. Wrijil, Katherine Bauer, Laurent Pessaint, Maciel Porto, Joseph Piegols, Andrew Faudree, Brittany Spence, Swagata Kar, Fatima Amanat, Florian Krammer, Hanne Andersen, Mark G. Lewis, Frank Wegmann, Roland Zahn, Hanneke Schuitemaker, and, D. H. Barouch, Immunity elicited by natural infection or Ad26.COV2.S vaccination protects hamsters against SARS-CoV-2 variants of concern Sci. Transl. Med. (2021).

65. B. Langmead, S. L. Salzberg, Fast gapped-read alignment with Bowtie 2. Nat. Methods 9, 357-359 (2012). doi:10.1038/nmeth.1923 Medline

Acknowledgments: We wish to thank Dr. J. Lim for the Flow Cytometry and Dr. F. Krammer for providing the recombinant SARS-CoV-2 Spike protein. Funding This work was funded by generous support from the Marc Haas Foundation. Author contributions: B.T. supervised and funded the project. S.H., K.O. designed and performed the experiments. L.C., J.F., R.M., M.P., contributed to conducting the experiments. J.F. performed bioinformatics analysis. S.H., K.O. and B.T. wrote the manuscript. Competing interests: The authors declare no competing interests Data and material availability: All the data can be found in the main text and supplemental material. RNA-Seq data from Fig. 1 can be obtained from the NCBI Gene Expression Omnibus (GSE147507). This work is licensed under a Creative Commons Attribution 4.0 International (CC BY 4.0) license, which permits unrestricted use, distribution, and reproduction in any medium, provided the original work is properly cited. To view a copy of this license, visit https://creativecommons.org/licenses/by/4.0/. This license does not apply to figures/photos/artwork or other content included in the article that is credited to a third party; obtain authorization from the rights holder before using this material.

Submitted 8 September 2021

Accepted 20 October 2021

Published First Release 26 October 2021

10.1126/sciimmunol.abm3131 
Fig. 1. Delayed induction of innate immune response in SARS-CoV-2 contributes to delay clearance. (A-B) Virus titers of IAV and SARS-CoV2WA in hamster lungs at each time point. Hamsters were intranasally inoculated with $10^{3}$ PFU of SARS-CoV-2WA or $10^{5}$ PFU of IAV, and harvested at 1 , 3,5 or 7days post-infection (dpi). (C-D) Heatmap depicting the expression levels of NF-kBrelated genes containing chemokines differentially expressed in lung samples of hamsters at 3 and $5 \mathrm{dpi}$. (E) GSEA analysis using NF-kB (top) and chemokine (bottom) signaling pathway gene sets was conducted on differential expression data generated from a direct comparison of SARS-CoV-2WA- and IAVinfected lung tissues on 3dpi in red, 5dpi in blue. (F) mRNA expression level of ISG15, IRF7, Cxcl10 and CCL5 represented by qRT-PCR. RNA samples of lungs from IAV- or SARS-CoV2WA-infected hamsters at 3 and 5dpi were assessed. All data was generated with error bars denote standard deviation across samples $(n=4)$.
A

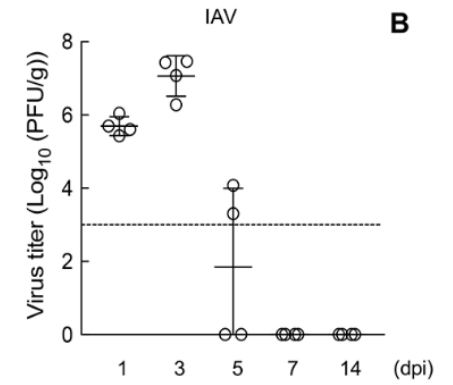

C

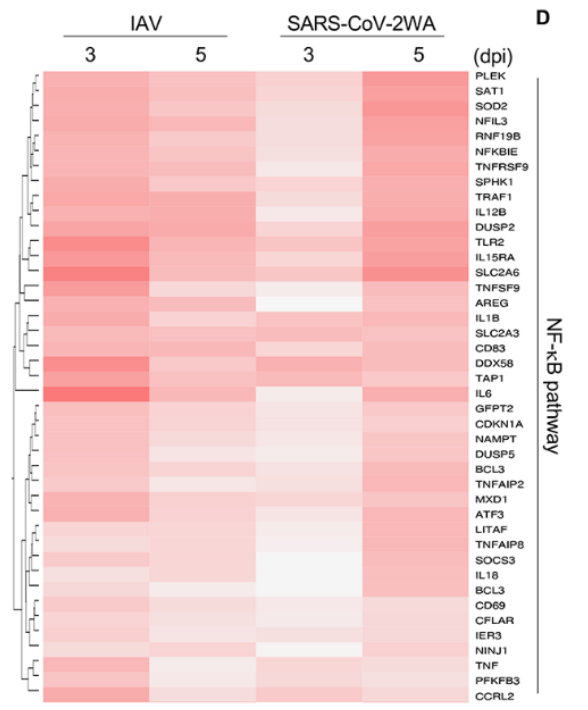

E

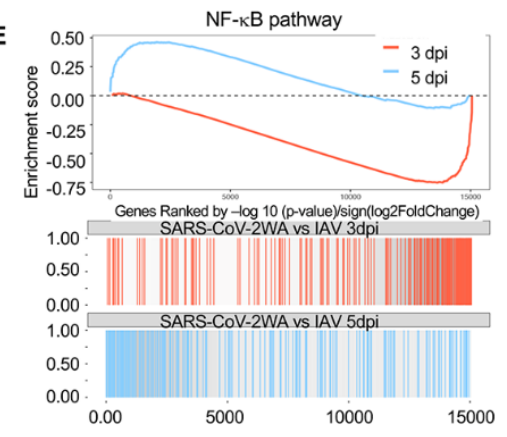

F

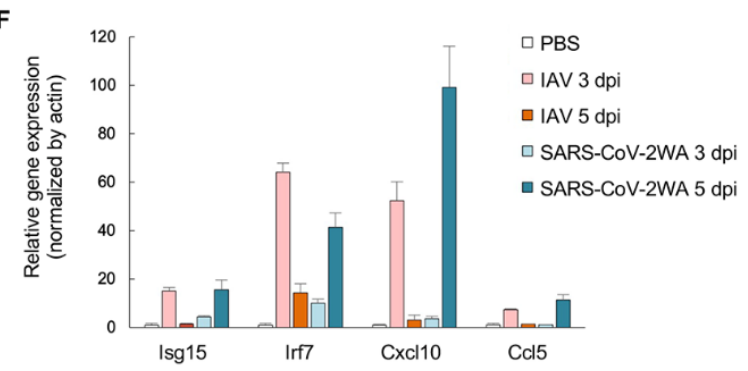

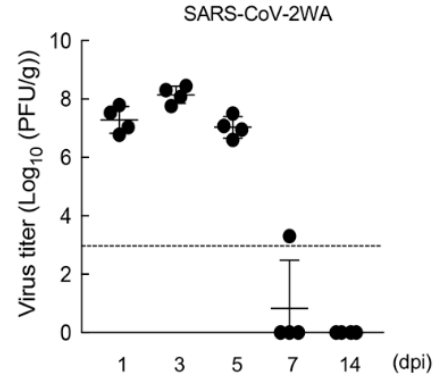

D
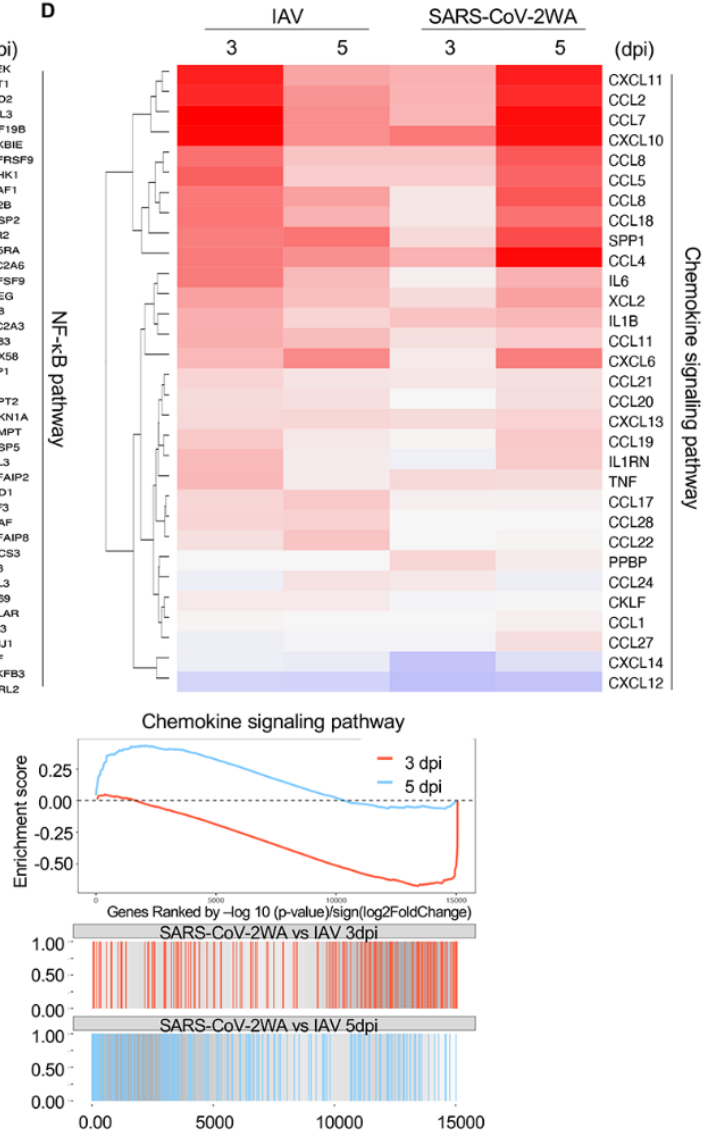

15000

. 
A

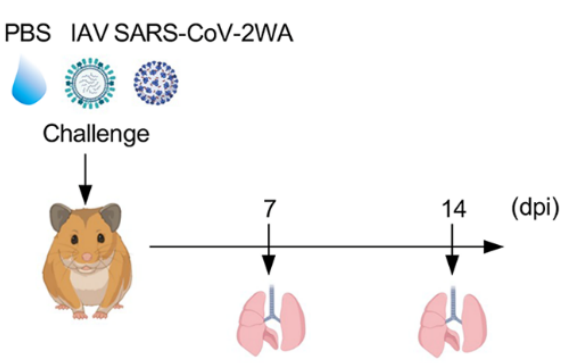

C

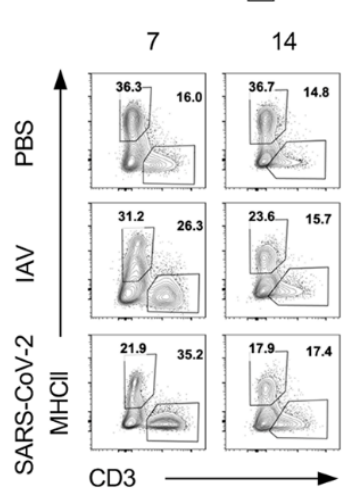

B

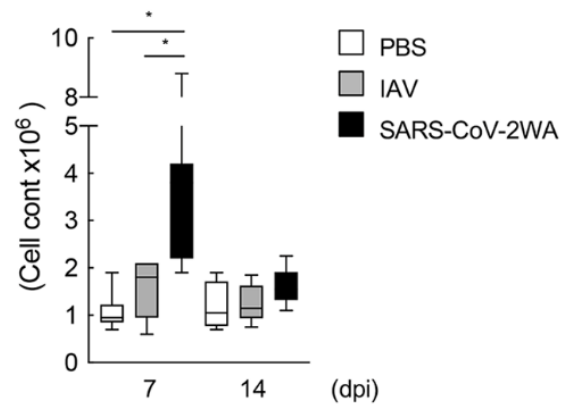

D

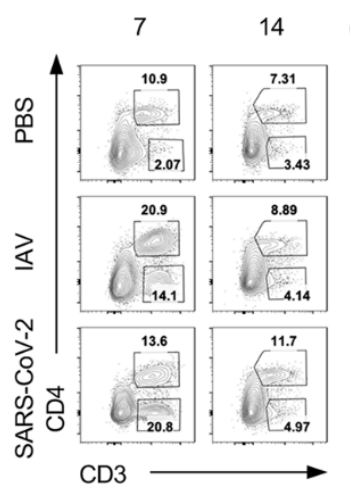

(dpi) $\mathrm{CD} 4+\mathrm{CD} 3+$

(CD4)

CD4-CD3+

(CD8)
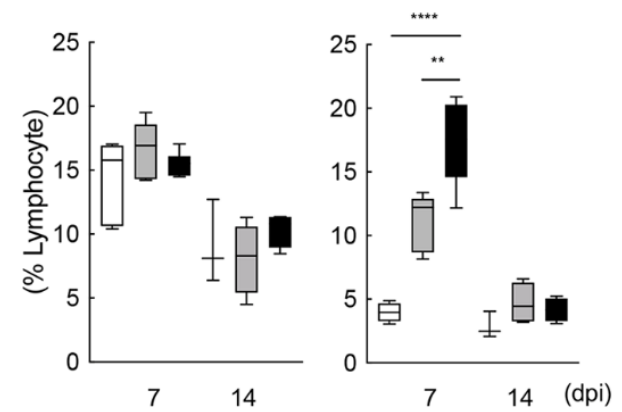

E

CD4

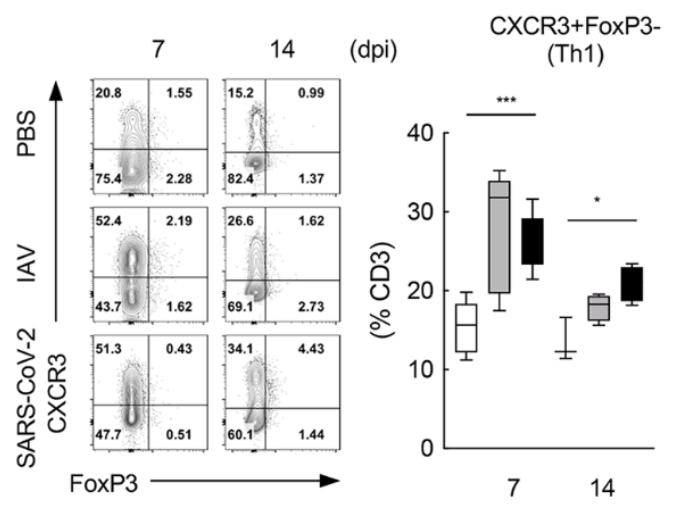

CXCR3-FoxP3+

(Treg)

CXCR3+FoxP3+

$\square$ PBS

$\square$ IAV
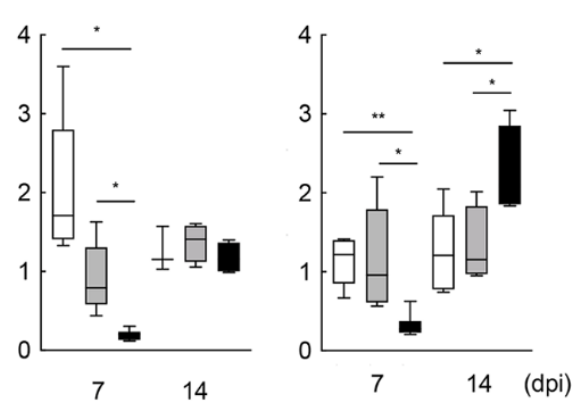

- SARS-COV-2WA
F

CD4

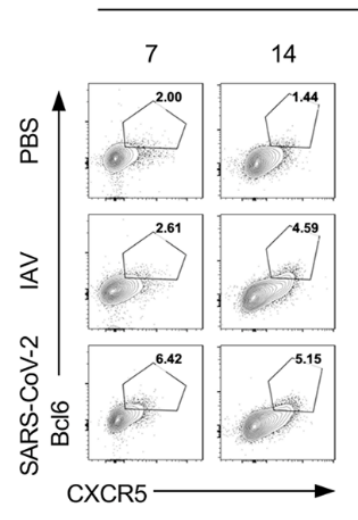

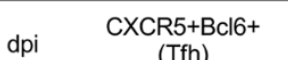

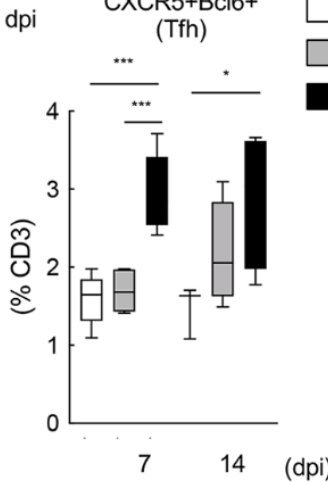

G

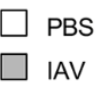

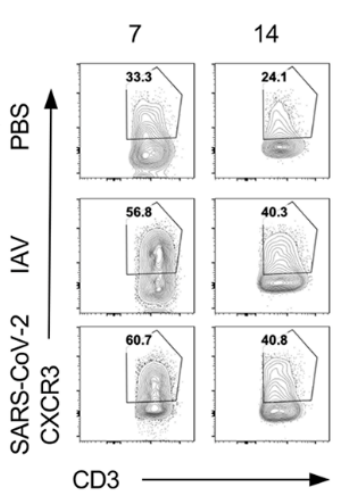

CD8
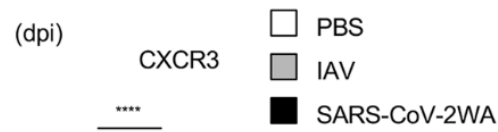

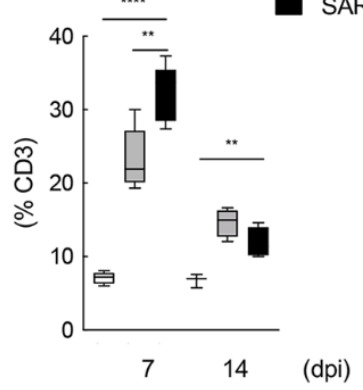


Fig. 2. Adaptive immunity to SARS-CoV-2 infection exceeds the response to IAV (A) Experimental protocol of hamster infection. Syrian golden hamsters were infected intranasally with either mock, $10^{5} \mathrm{PFU}$ of IAV or $10^{3} \mathrm{PFU}$ of SARS-CoV-2WA. Lung cells were collected at day 7 and 14 post infection to analyze T and B cells by FACS. (B) Total count of cells collected from the lung after specific gravity separation with ficol. (C-D) Frequency of MHCll-CD3+ T cells in the lung (C) and CD3+CD4+ T cells and CD8+ T cells (CD3+CD4-) (D). (E) Frequency of Th1 (CXCR3+FoxP3-), Tregs (CXCR3+ FoxP3+), CXCR3+Tregs (CXCR3+FoxP3+) after gating on CD3+CD4+ T cells. (F) frequency of Tfh (CXCR5+Bcl6+) after gating on CD3+CD4+ T cells. (G) Frequency of CXCR3+CD8+ T cells (CXCR3+) within CD3+CD4- cells. Data are from the indicated time points after virus infection. Representative FACS plot (left panel) along with the data set of the frequency with 3 to 7 individuals are shown (right panel). ${ }^{*} P<0.05{ }^{*} P<0.01{ }^{* * *} P<0.001$ 
A PBS SARS-CoV-2WA

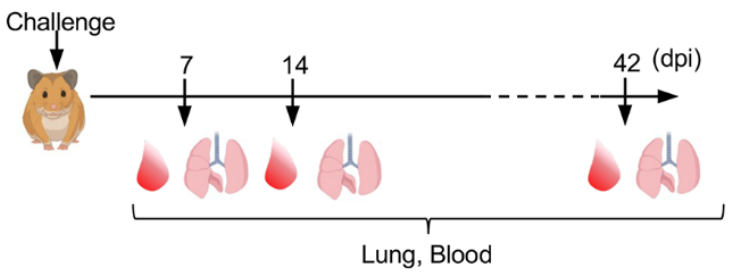

B

O PBS - SARS-CoV-2WA

C

O PBS - SARS-CoV-2WA

Ki67+IRF4+ CD4+ T cell
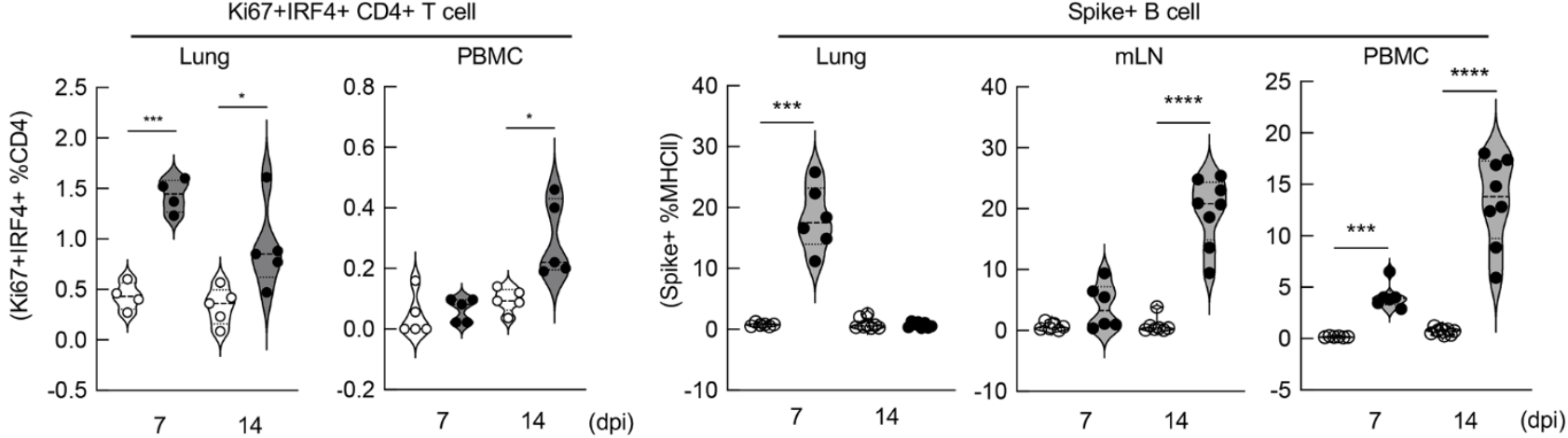

D

O PBS - SARS-CoV-2WA

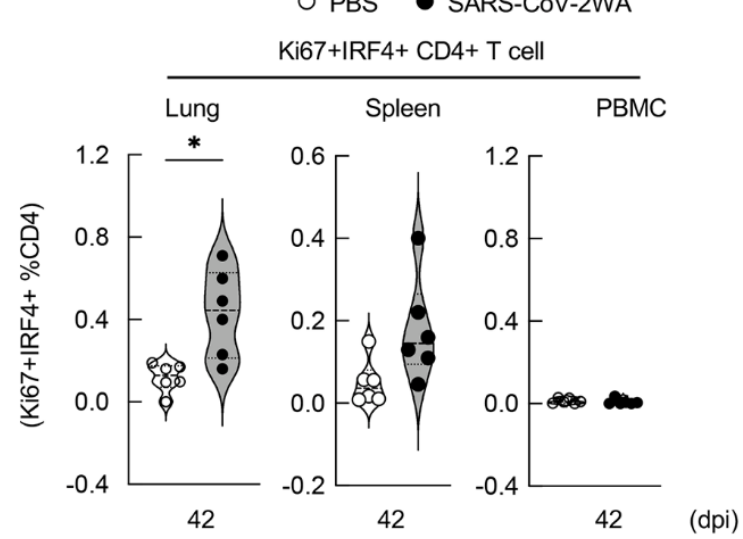

E

O PBS - SARS-CoV-2WA
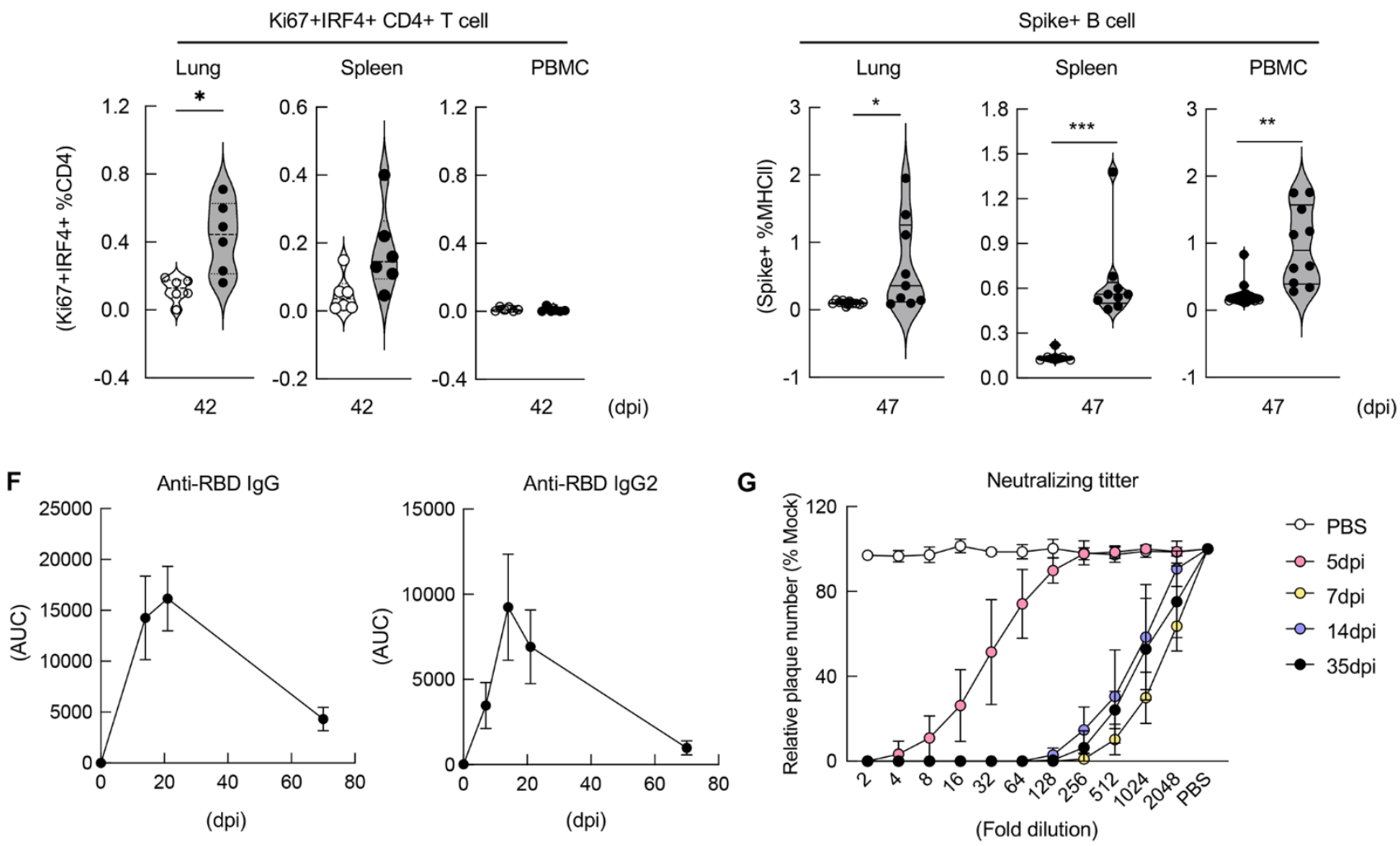
Fig. 3. Antigen-specific $T$ and $B$ cells generated after SARS-CoV-2 infection are maintained as memory cells (A) Experimental protocol of hamster infection. Syrian golden hamsters were infected intranasally with either mock, $10^{5} \mathrm{PFU}$ of IAV or $10^{3} \mathrm{PFU}$ of SARS-CoV-2WA. Lungs, mLNs, PBMCs, and spleens were collected at day 7,14 and over 40 dpi to analyze antigen-specific $T$ and $B$ cell by FACS. (B) Frequency of Ki67+IRF4+ CD4+ T cells as SARS-CoV-2-specific CD4+ T cells in the lungs and PBMCs at 7 and 14 dpi. (C) Frequency of SARS-CoV-2 S-specific B cells in the lungs, mLNs, and PBMCs at 7 and 14 dpi. (D) Frequency of Ki67+IRF4+ CD4+ T cells as SARS-CoV-2-specific CD4+ T cells in the lungs and PBMCs at 42 dpi. (E) Frequency of SARS-CoV-2 S-specific B cells in the lungs, $\mathrm{mLNs}$, and PBMCs at $47 \mathrm{dpi}$. (F) IgG and IgG2 antibody titer against SARS-CoV-2 receptor binding domain from the serum after SARS-CoV-2WA infection at the indicated timepoints. (G) Plaque reduction assay from the serum after SARS-CoV-2WA infection at the indicated timepoints. The 50\% plaque reduction neutralization test (PRNT50) is defined as the highest serum dilution resulting in $50 \%$ reduction in plaque formation units. The PRNT50 of each sample was calculated using a nonlinear regression analysis for a four parameter logistic sigmoidal curve. PRTN50: 5dpi, 30.63, 7dpi, 1550.00, 14dpi, 829.30, 35dpi, 988.30. A representative data set of 4 to 9 individuals is shown. ${ }^{*} P<$ $0.05 * * P<0.01 * * * P<0.001$ 
A
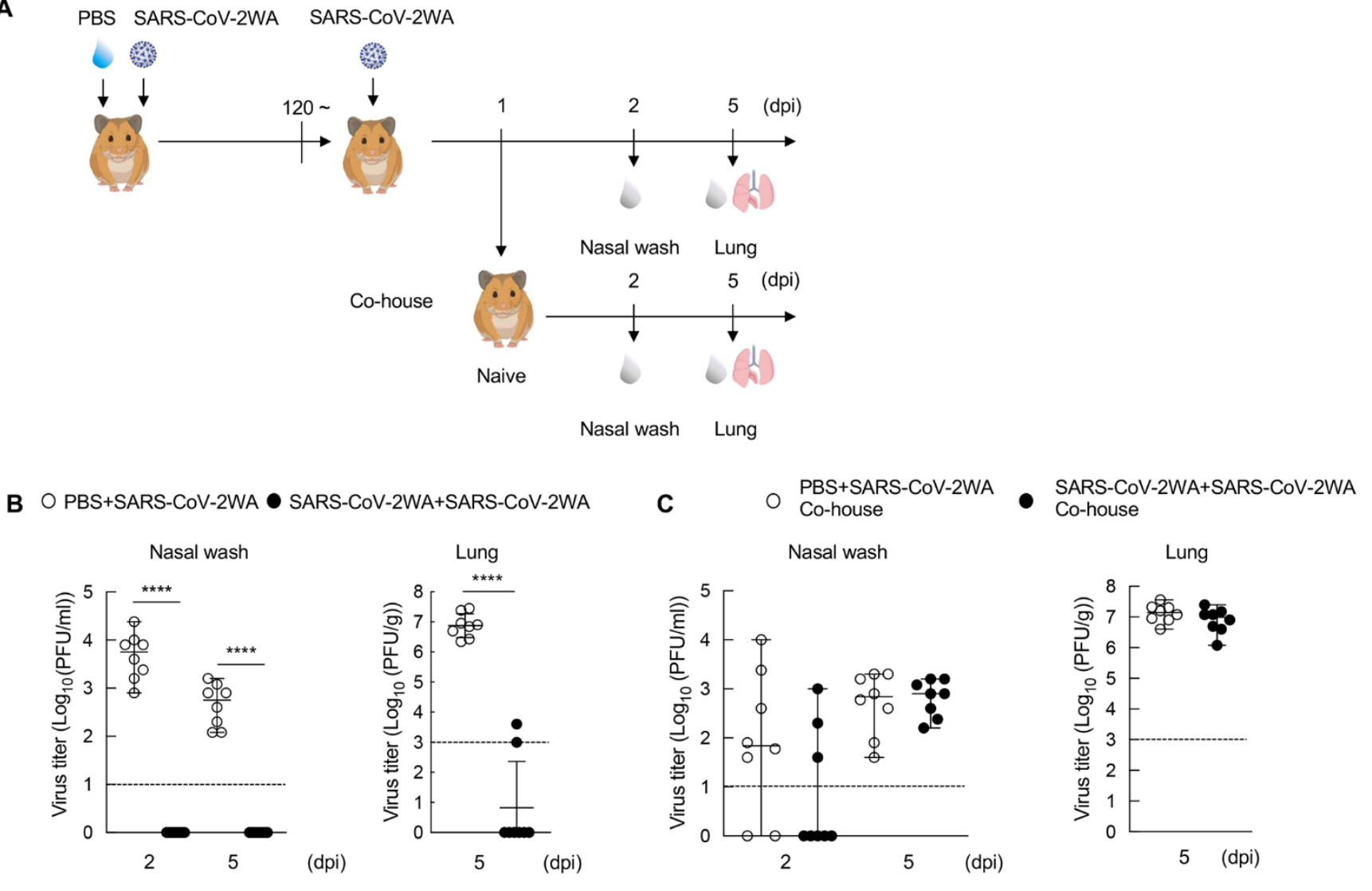

Fig. 4. Adaptive immunity protects the host but does not prevent transmission after secondary exposure to SARS-CoV-2 (A) Experimental protocol for hamster re-challenge and transmission. Syrian golden hamsters infected intranasally with either mock or $10^{3}$ PFU of SARS-CoV-2WA were rechallenged with the same SARS-CoV-2WA strain after more than 120 days post primary infection. For transmission, naïve hamsters were co-housed with the re-challenged hamsters, one-to-one, one day post re-challenge in a new cage. Nasal wash was collected at 2- and 5-days post re-challenge and lungs were collected at 5 days post rechallenge to analyze plaque forming units. (B) Plaque forming units from nasal wash at 2 and $5 \mathrm{dpi}$ (left) and the lungs at $5 \mathrm{dpi}$ (right) in re-challenged hamsters. (C) Plaque forming units from nasal wash at 2 and $5 \mathrm{dpi}$ (left) and the lungs at $5 \mathrm{dpi}$ (right) in co-housed hamsters with the re-challenged hamsters. A representative data set of 8 individuals is shown. ${ }^{* *} P<0.001$ 
A

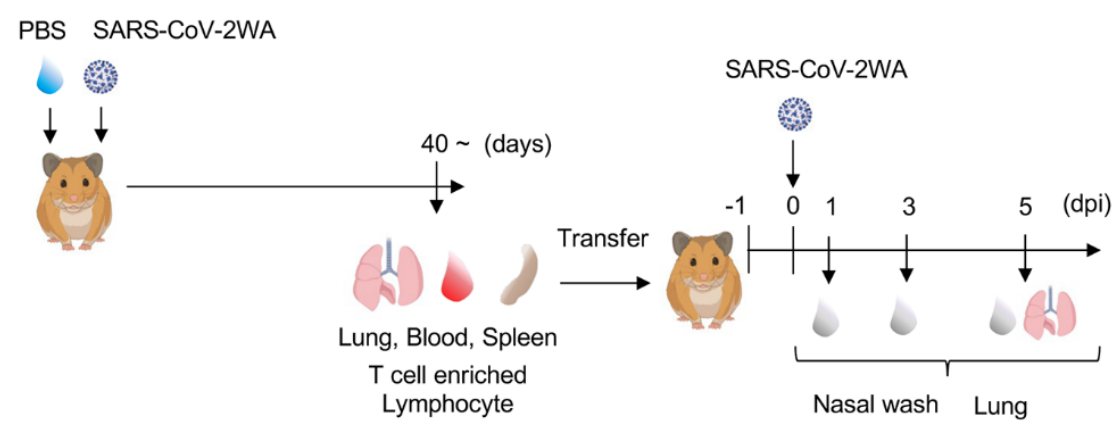

B

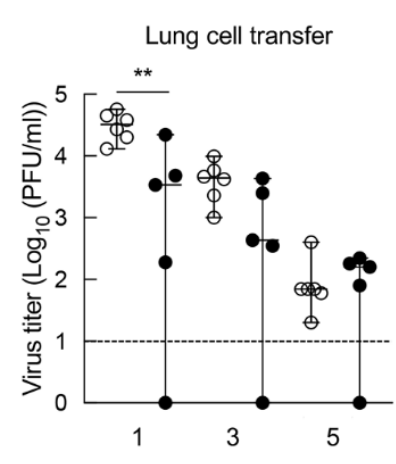

○ Control

- SARS-CoV-2WA recovered

PBMC cell transfer

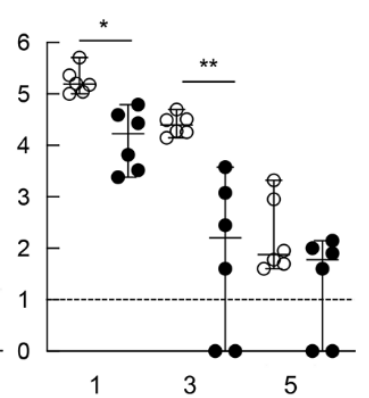

Spleen cell transfer

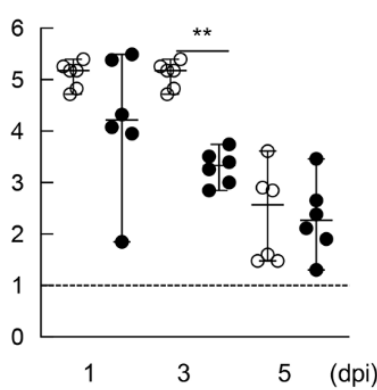

C

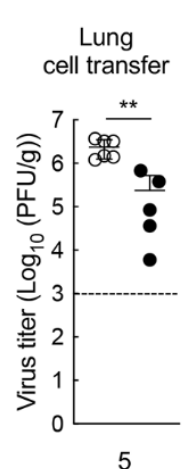

- SARS-CoV-2WA recovered $\begin{array}{cc}\text { PBMC } & \text { Spleen } \\ \text { cell transfer } & \text { cell transfer }\end{array}$

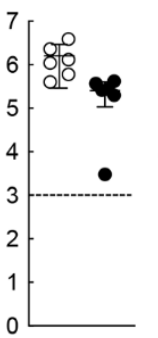

5

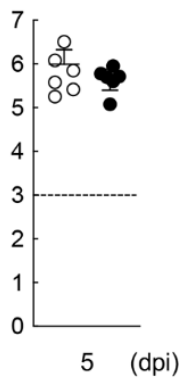

D O Control

- SARS-CoV-2WA recovered

Spike+ B cell

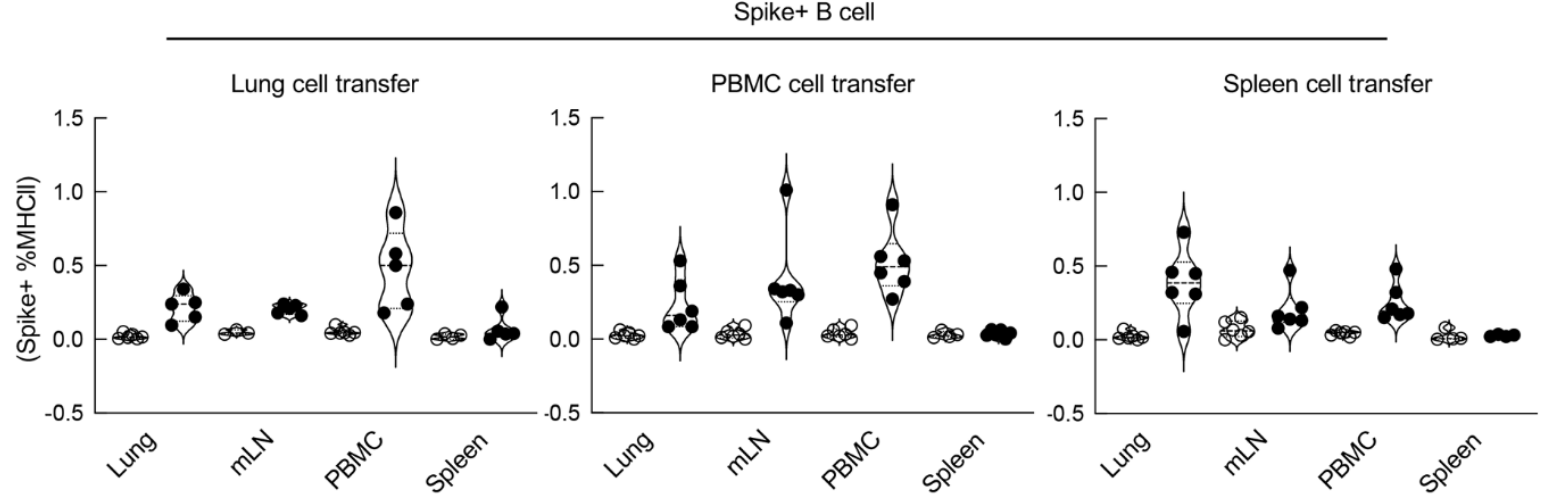

Fig. 5. SARS-CoV-2-specific memory $T$ cells contribute to viral clearance (A) Experimental protocol for $T$ cellenriched population transfer and re-challenge. Lymphoid cells from lungs, PBMCs, and spleen from golden hamsters infected with either mock or $10^{3}$ PFU of SARS-CoV-2WA after more than 40 days were collected. After MHC-II+ cell depletion, cells were adoptively transferred to a naïve hamster following SARS-CoV-2WA intranasal infection. Nasal wash was collected at 1-, 3- and 5-days post re-challenge, and lungs were collected at $5 \mathrm{dpi}$ to analyze plaque forming units. (B-C) Plaque forming units from nasal wash at 1-,3- and 5- dpi (B) and the lungs at 5 dpi infected hamsters that received adoptive transfers of $T$ cells $(C)$ from the lungs, PBMCs and spleens of hamsters previously infected with SARS-CoV-2WA. (D) Frequency of SARS-CoV-2 S-specific B cells in the lungs, mLNs, PBMCs, and spleens at 5dpi in infected hamsters that received adoptive transfers of T cells $(C)$ from the lungs, PBMCs and spleens of hamsters previously infected with SARS-CoV-2WA. A representative data set of 5 to 6 individuals is shown. Data from 2-3 representative for each experiment is shown. ${ }^{*} P<0.05 * * P<0.01 * * * 0.001$ 
A

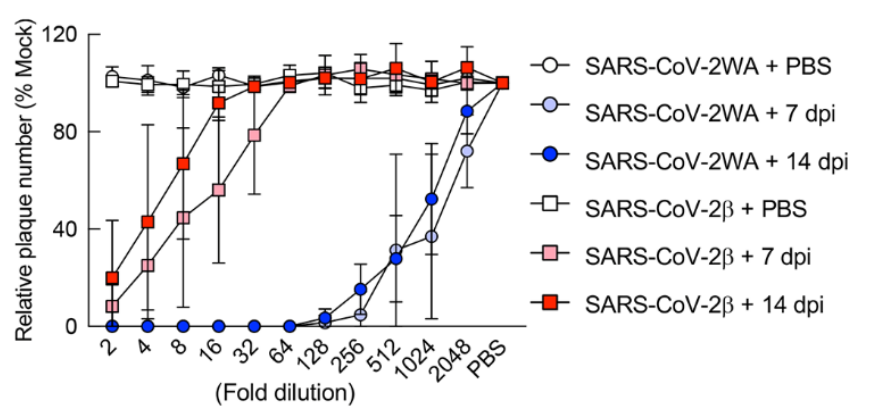

B

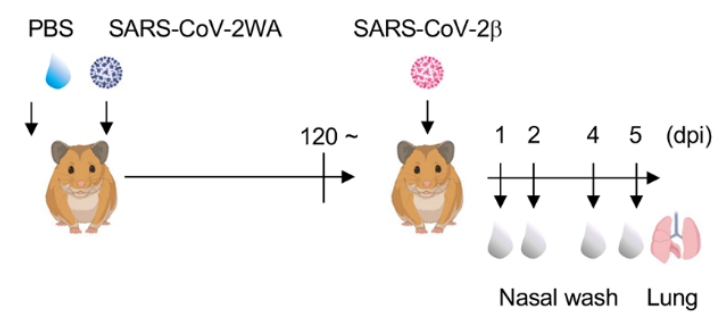

C

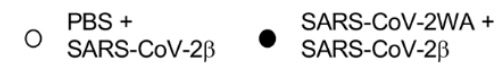

Nasal wash
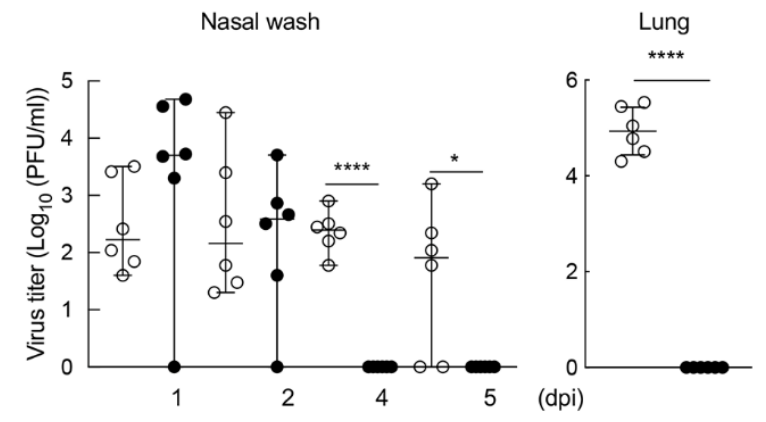

D

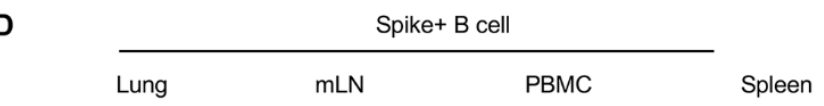

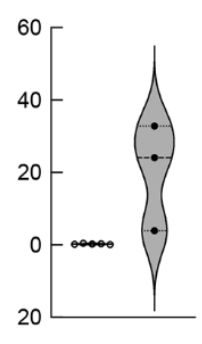
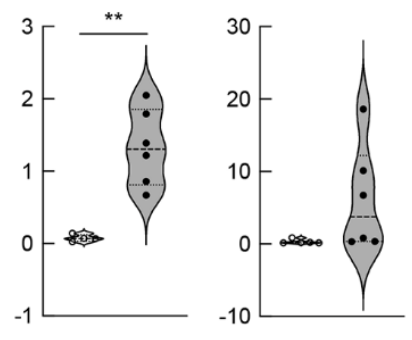

E

PBS +
SARS-CoV-2 $\beta$

SARS-CoV-2WA +
SARS-CoV-2 Anti-RBD IgG Anti-RBD IgG2
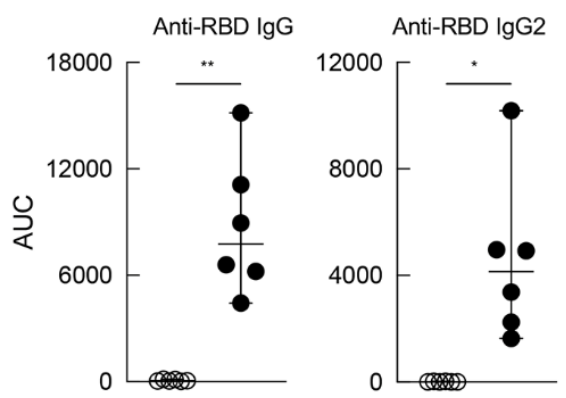

$\mathbf{F}$
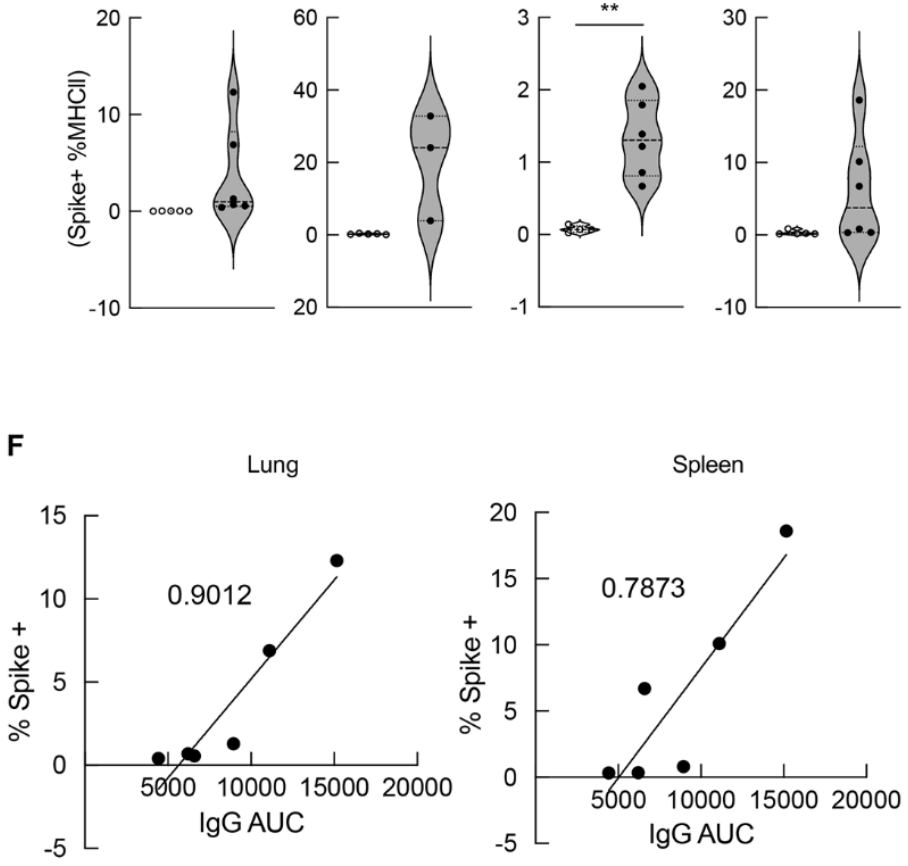

G
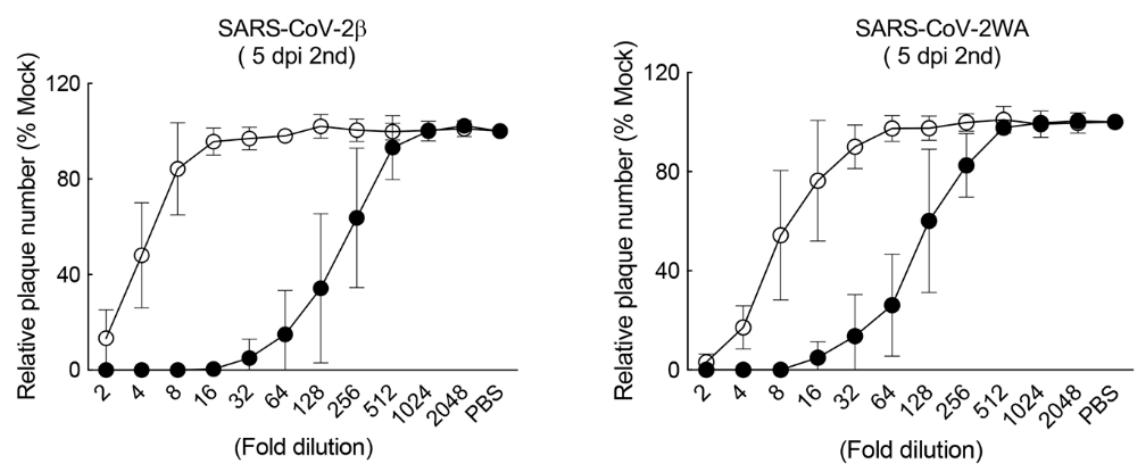

PBS +

SARS-CoV-2 $\beta$

- SARS-CoV-2WA +

- SARS-CoV-2 $\beta$ 
Fig. 6. Memory $B$ and T cells generated after SARS-CoV-2 infection contributes to SARS-CoV-2 variant clearance (A) Plaque reduction assay from the SARS-CoV-2WA infection hamster serum at 7 and $14 \mathrm{dpi}$ against SARS-CoV-2WA and SARS-CoV- $2 \beta$ variant. The $50 \%$ plaque reduction neutralization test (PRNT50) is defined as the highest serum dilution resulted in 50\% reduction in plaque formation units. The PRNT50 of each sample was calculated by was calculated by using a non-linear regression analysis for a four parameter logistic sigmoidal curve. PRTN50: SARS-CoV-2WA+7dpi, 1030.00, SARS-CoV-2WA+14dpi, 896.20, SARSCoV-2 $\beta+7 d p i, 12.01$, SARS-CoV-2 $\beta+14 d p i$, 5.53. (B) Experimental protocol for SARS-CoV-2 $\beta$ variant rechallenge. Syrian golden hamsters infected intranasally with either mock or SARS-CoV-2WA were rechallenged with $10^{3}$ PFU of SARS-CoV- $2 \beta$ variant 120 days post primary infection. Nasal wash was collected at 1-, 2-, 4- and 5-days post re-challenge and lungs were collected at 5 days post re-challenge to analyze plaque forming units. (C) Plaque forming units from nasal wash at 1-, 2-, 4- and 5-days post re-challenge (left) and the lungs at 5 days post re-challenge (right) in SARS-CoV- $2 \beta$ variant re-challenged hamsters. (D) Frequency of SARS-CoV-2 S-specific B cells in the lungs after gating on MHCll+ cells, $\mathrm{mLNs}$, and PBMCs at 5 days post SARS-CoV-2 $\beta$ variant re-challenged hamsters. (E) IgG and IgG2 antibody titers against SARS-CoV-2 RBD from the serum from 5 days post SARS-CoV- $2 \beta$ variant re-challenged hamsters. ( $F$ ) Correlation of the frequency of $S$-specific B cells in the lungs and spleens in (D) and the AUC from the anti RBD-specific IgG titer in (E). Each dot indicates the result from individual hamsters. (G) Plaque reduction assay of the serum from 5 days post SARS-CoV- $2 \beta$ variant re-challenged hamsters against SARS-CoV- $2 \beta$ variant (left) and SARS-CoV-2WA (right). The $50 \%$ plaque reduction neutralization test (PRNT50) is defined as the highest serum dilution resulted in 50\% reduction in plaque formation units. The PRNT50 of each sample was calculated by was calculated by using a non-linear regression analysis for a four parameter logistic sigmoidal curve. PRNT50: PBS+SARS-CoV- $2 \beta, 7.01$, SARS-CoV-2WA+SARS-CoV- $2 \beta, 107.20$ (left), PBS+SARS-CoV-2 $\beta, 4.00$, SARSCoV-2WA+SARS-CoV-2 $\beta, 185.80$ (right). A representative data set of 3 to 4 individuals is shown. ${ }^{*}<0.05$ 